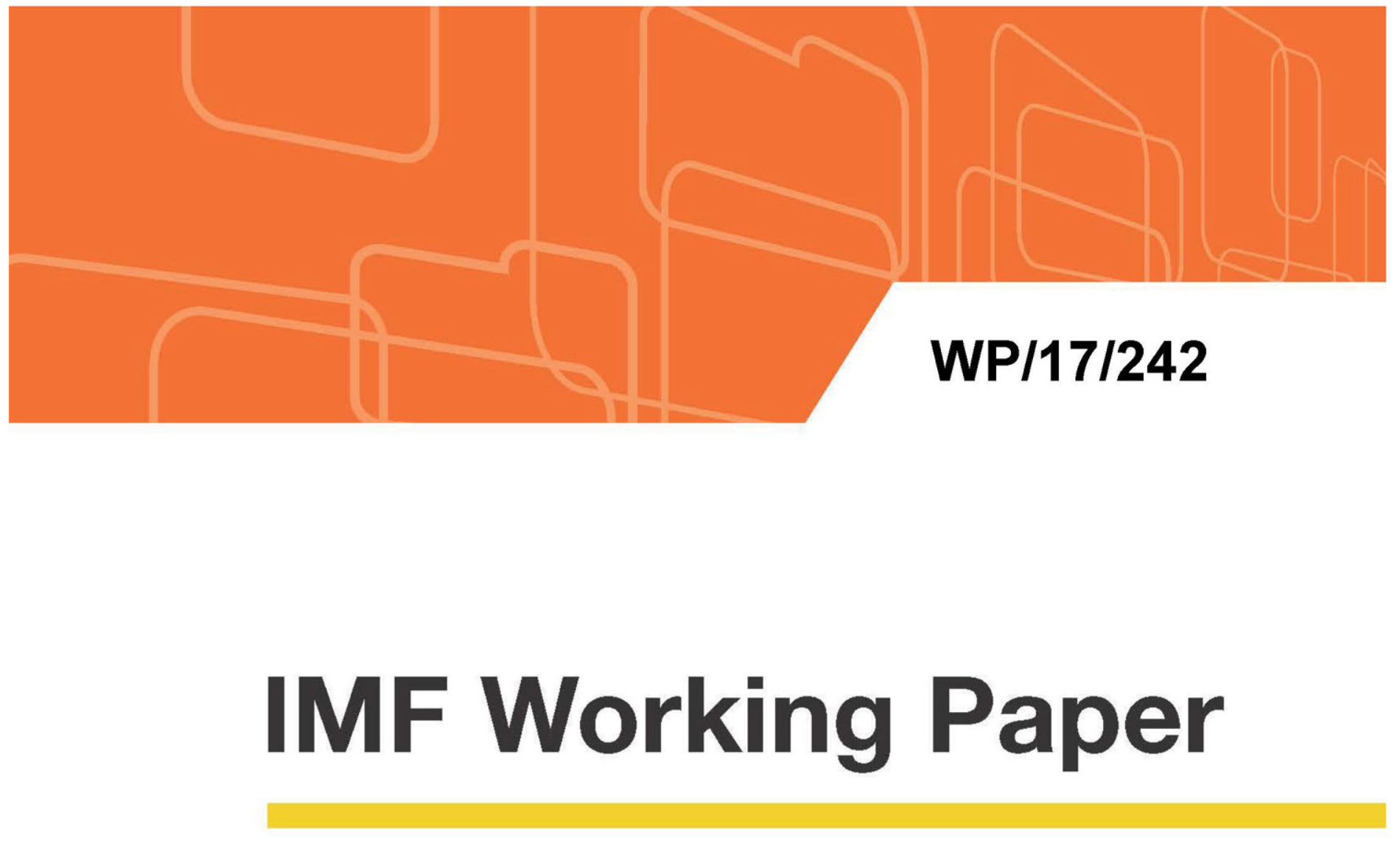

\title{
The Slowdown in Global Trade: A Symptom of A Weak Recovery
}

by Aqib Aslam, Emine Boz, Eugenio Cerutti, Marcos Poplawski-Ribeiro, and Petia Topalova

IMF Working Papers describe research in progress by the author(s) and are published to elicit comments and to encourage debate. The views expressed in IMF Working Papers are those of the author(s) and do not necessarily represent the views of the IMF, its Executive Board, or IMF management.

$$
\text { I N T E R N A T I O N A L M O N E T A R Y F U N D }
$$




\section{WP/17/242}

\section{IMF Working Paper}

\section{The Slowdown in Global Trade: A Symptom of A Weak Recovery}

by Aqib Aslam, Emine Boz, Eugenio Cerutti, Marcos Poplawski-Ribeiro, and Petia Topalova

IMF Working Papers describe research in progress by the author(s) and are published to elicit comments and to encourage debate. The views expressed in IMF Working Papers are those of the author(s) and do not necessarily represent the views of the IMF, its Executive Board, or IMF management.

$$
\text { I N T E R N A T I O N A L M O N E T A R Y F U N D }
$$




\title{
IMF Working Paper
}

\author{
Research Department
}

\section{The Slowdown in Global Trade: A Symptom of A Weak Recovery ${ }^{1}$ \\ Prepared by Aqib Aslam, Emine Boz, Eugenio Cerutti, Marcos Poplawski-Ribeiro, and Petia Topalova ${ }^{2}$}

Authorized for distribution by Oya Celasun

November 2017

\begin{abstract}
IMF Working Papers describe research in progress by the author(s) and are published to elicit comments and to encourage debate. The views expressed in IMF Working Papers are those of the author(s) and do not necessarily represent the views of the IMF, its Executive Board, or IMF management.
\end{abstract}

\begin{abstract}
Global trade growth has slowed since 2012 relative both to its strong historical performance and to overall economic growth. This paper aims to quantify the role of weak economic growth and changes in its decomposition in accounting for the slowdown in trade using a reduced form and a structural approach. Both analytical investigations suggest that the overall weakness in economic activity, particularly investment, has been the primary restraint on trade growth, accounting for over 80 percent of the decline in the growth of the volume of goods trade between 2012-16 and 2003-07. However, other factors are also weighing on trade in recent years, especially in emerging market and developing economies, as evidenced by the non-negligible role attributed to trade costs by the structural approach.
\end{abstract}

\section{JEL Classification Numbers: F1, F4, F10, F14, F17, F44}

Keywords: International Trade, Globalization, Trade Policy, Investment

Author's E-Mail Address: aaslam@imf.org, eboz@imf.org, ecerutti@imf.org, mpoplawskiribeiro@,imf.org, ptopalova@imf.org

\footnotetext{
${ }^{1}$ We thank Oya Celasun, Julian di Giovanni, Caroline Freund, Andrei Levchenko, Gian Maria Milesi-Ferretti, Brent Neiman, Maury Obstfeld, and Walter Steingress, as well as participants in the BNM-IMF-IMFER Conference on Globalization After the Crisis, IMF Brown Bag seminar and the 2016 ECB-BoF Workshop organized by the Task Force on Global Trade for helpful comments and suggestions. Ava Yeabin Hong, Hao Jiang, Evgenia Pugacheva, Rachel Szymanski, and Hong Yang provided excellent research assistance. The views expressed in this paper are those of the authors and do not necessarily represent those of IMF or IMF policy. An earlier version of much of the analysis presented in this paper was published in several sections of Chapter 2 of the October 2016 World Economic Outlook.

${ }^{2}$ All authors are at the International Monetary Fund.
} 


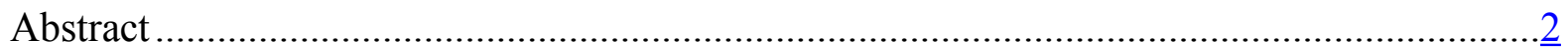

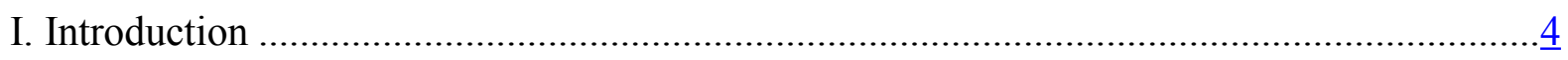

II. The Slowdown of Trade Growth: Some Sytized Facts ................................................ 7

III. The Role of Ouput and Its Composition: Insights from an Empirical Investigation ............ $\underline{8}$

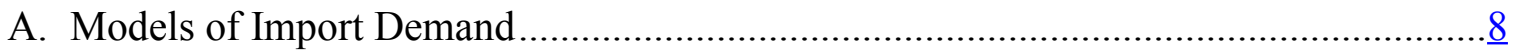

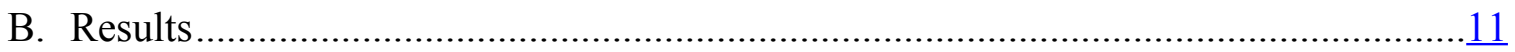

IV. The Role of Demand Composition and Trade Costs: Insights from a Structural Investigation.

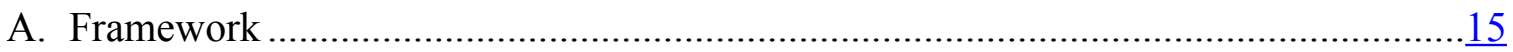

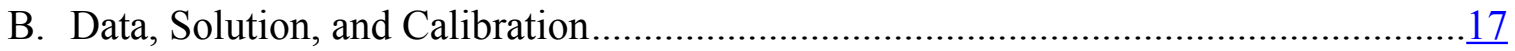

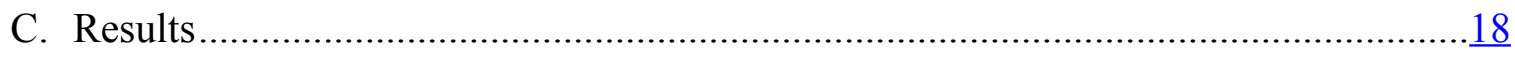

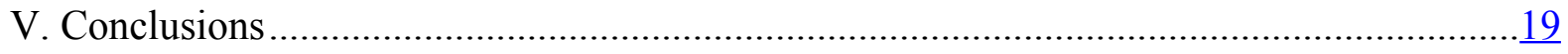

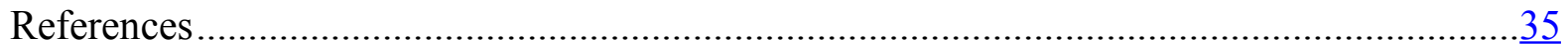

\section{Figures}

1. World Real Trade and GDP Growth in Historical Perspective .........................................21

2. Trade in Values, Volumes, Across Country Groups, and Types of Products.....................22

3. Empirical Model: Actual and Predicted Growth of Real Goods and Services Imports,

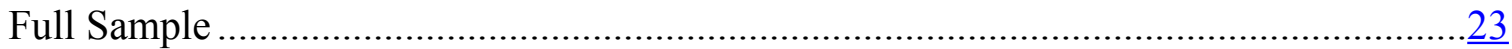

4. Empirical Model: Difference Between Actual and Predicted Growth of Real Growth

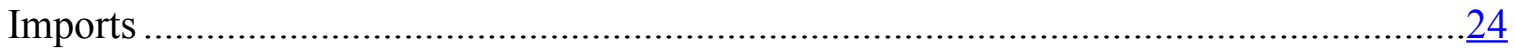

5. Empirical Model: Decomposing the Slowdown in Real Goods Imports Growth ...............25

6. Structural Model: Actual and Model Implied Evolution of Nominal Import-to-GDP

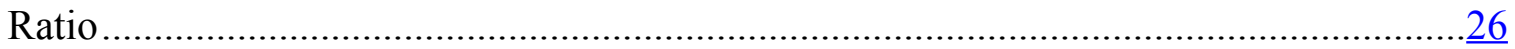

7. Structural Model: Demand Composition Wedges ….....................................................

\section{Tables}

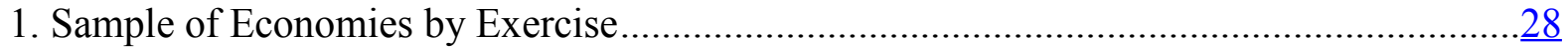

2. Import Content of Aggregate Demand Components ................................................ 28

3. Empirical Model of Real Imports of Goods and Services ..............................................29

4. Empirical Model of Real Imports of Goods ..............................................................29

5. Empirical Model of Real Imports of Services ...................................................... $\underline{30}$

6. Residuals: Real Goods Import Growth ..............................................................

7. Residuals: Real Services Import Growth ..............................................................

8. Decomposing the Decline in Real Goods Import Growth: Full Sample ........................... $\underline{32}$

9. Decomposing the Decline in Real Goods Import Growth: Advanced Economies ...............33

10. Decomposing the Decline in Real Goods Import Growth: Emerging Market and

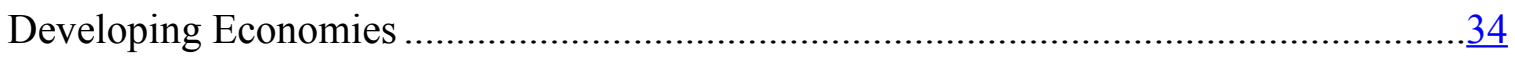




\section{INTRODUCTION}

Global trade growth has decelerated significantly in recent years. After its sharp collapse and even sharper rebound in the aftermath of the global financial crisis, the volume of world trade in goods and services has grown by just over 3 percent a year since 2012, less than half the average rate of expansion during the previous three decades. The slowdown in trade growth is remarkable, especially when set against the historical relationship between growth in trade and global economic activity (Figure 1). Between 1985 and 2007, real world trade grew on average twice as fast as global GDP, whereas over the past five years, it has barely kept pace. Such prolonged sluggish growth in trade volumes relative to economic activity has few historical precedents during the past five decades.

The reasons for the weakness in global trade growth are still not clearly understood, yet a precise diagnosis is necessary to assess if and where policy action may help. How much of the waning of trade is a symptom of the generally weak economic environment? Private investment has remained subdued across many advanced and emerging market and developing economies in the aftermath of the global financial and European debt crises (see IMF, 2015), and China has embarked on a necessary process of rebalancing away from investment and toward more consumption-led growth. Many commodity exporters have cut capital spending in response to persistently weak commodity prices. Since investment relies more heavily on trade than consumption, Freund (2016) argues that an investment slump would inevitably lead to a slowdown in trade growth (see also Boz, Bussière, and Marsilli 2015 and Morel 2015, for example). Other factors could also be contributing to the trade slowdown. The waning pace of trade liberalization over the past few years and the recent uptick in protectionist measures could be limiting the sustained policy-driven reductions in trade costs achieved during 1985-2007, which provided a strong impetus to trade growth (Evenett and Fritz 2016; Hufbauer and Jung 2016). The formation of cross-border production chains may have slowed—possibly because their growth matured or because the cost of trade fell more modestly, or both-implying a slower expansion in such supply chain-related trade (Constantinescu, Mattoo, and Ruta 2015).

In this paper, we explore the reasons for the weakness in trade since 2012 using two complementary analytical approaches. ${ }^{3}$ We first estimate a standard empirical model of demand for goods' imports to determine whether import growth at the country level has slowed by more than changes in aggregate demand components and relative prices would predict in recent years. Following Bussière et al (2013), we proxy import demand with the import-intensity-adjusted aggregate demand - a weighted average of investment, private and government consumption, and exports - to account explicitly for differences in the import content of the various aggregate demand components, and to capture the effect of changes in the overall strength of economic

\footnotetext{
${ }^{3}$ Constantinescu, Mattoo and Ruta 2015 argue that the decline in trade growth relative to economic growth may have begun in the early 2000s. Since their finding hinges to a significant extent on the choice of measurement to aggregate global trade and GDP, we follow the vast majority of the literature and focus on the sharp decline in trade volume growth since the end of 2011 (see also Ollivaud and Schwellnus, 2015, and OECD, 2016).
} 
activity and across its drivers. In light of the global nature of the trade slowdown, we further improve on the Bussière et al (2013) framework and aggregate more consistently across countries predicted changes in trade driven by domestic demand at home and in trading partners. A single country can take external demand for its goods as given, but for the world as a whole only the sum of individual countries' domestic demands determines global trade growth.

An even more suitable way to tackle the synchronised nature of the trade slowdown across countries is through the lens of a structural multi-country, multi-sectoral model of trade. In our second approach, we complement the empirical analysis by estimating a structural multicountry, multisector model inspired by Eaton et al. $(2010,2016)$. The analysis quantifies the importance of changes in the composition of demand and other factors, such as trade costs broadly defined - in a global setting. The general equilibrium approach has an additional advantage as it allows the level of economic activity to respond endogenously to changes in trade patterns and trade costs, through their effects on prices of intermediate and consumption goods. This is a channel our empirical model is unable to capture.

We find that the overall weakness in economic activity appears to be a key restraint on trade growth since 2012. The empirical model of import demand, estimated separately for 150 economies over 1985-2016, suggests that from the perspective of an average individual country, a very large share of the decline in real import growth since 2012 can be traced to weaker investment and subdued export demand. World goods trade volume growth averaged 2.2 percent $\%$ in 2012-16, down from 8.1 percent in 1985-2007 and 9.0 percent in 2003-07. Our empirical model can predict over 80 percent of the 6.8 percentage points shortfall in real goods import growth since 2012 compared with 2003-07 and about 70 percent of the 5.9 percentage points shortfall compared to 1985-2007. These declines reflect slower overall growth, a change in the composition of economic activity away from more import-intensive components - namely, investment - and the synchronised nature of the growth slowdown across countries, which may be in part affected by trade. However, factors beyond the level and composition of demand are also weighing on trade growth, shaving up to $1 \frac{3}{4}$ percentage points off global real import growth during 2012-16.

The general equilibrium model, estimated for 34 advanced and emerging market economies, similarly finds that changes in the composition of demand explain about 60 percent of the slowdown in the growth of the ratio of nominal goods to GDP in 2012-16 relative to 2003-07. At the same time, trade costs - which, in the model, encompass tariffs, non-tariff barriers, cross-border transportation costs, etc. - play a non-negligible role, accounting for close to a quarter of the slowdown. Their contribution to the decline in trade growth observed in 
emerging market economies is even larger. This mirrors the empirical model's finding of a more pronounced missing of trade growth since 2012 in emerging market and developing economies. ${ }^{4}$

It is important to emphasize from the outset that providing a precise quantification of the role of economic activity in the evolution of trade flows is inherently a difficult task. Demand for traded goods is clearly a function of economic growth, but international trade and trade policies can also shape economic activity by influencing firms' investment decisions, their access to intermediate inputs, production processes, and productivity. For example, the fading pace of trade liberalization since the early 2000s may have contributed to slow productivity growth, weak investment, and lackluster output growth in recent years. As in the vast majority of the trade literature, our empirical analysis focuses only on part of this complex web of relationships, as our primary goal is to establish whether recent trade dynamics are consistent with the observed level and composition of output growth given historical patterns of association. The structural analysis takes a more holistic approach as, in general equilibrium, the level of economic activity, production structure, and trade patterns are jointly determined by trade costs, preferences, and productivity. However, due to its stylized representation of the real world, the model is unable to capture all the channels through which trade may affect output.

Our study contributes to a growing literature that seeks to understand the behavior of trade around the global financial crisis and the associated "Great Trade Collapse", and in the recent slowdown period. ${ }^{6}$ While a number of studies examine the role of weak growth and its composition in the decline in trade growth (see, for example, Amiti et al. (2016), ECB (2016), Kindberg-Hanlon and Young (2016), Morel (2015), Ollivaud and Schwellnus (2015)), our study is the first to complement a disaggregate empirical analysis for over 150 countries going back to 1985 and a multi-country general equilibrium approach. The latter is particularly suitable to understanding the trade slowdown given its widespread nature and in light of the existing feedback loops between international trade and economic activity.

In addition, we make a couple of methodological contributions. In our empirical analysis, we provide extensions to the Bussière et al. (2013) framework by using external demand predicted by trading partners' domestic demand, rather than actual exports. This extension allows us to more consistently aggregate predicted changes in trade driven by domestic demand at home

\footnotetext{
${ }^{4}$ Using disaggregated product and bilateral-sectoral trade flows, Aslam et al (forthcoming) attempt to disentangle the role of policy-related trade costs, such as tariff and non-tariff barriers, and changes in the pace of global value chain expansion in the global trade slowdown.

${ }^{5}$ See Baldwin 2009 and papers therein, Bussière et al (2013), Eaton et al. (2016), Levchenko, Lewis and Tesar (2010), among others.

${ }^{6}$ Hoekman 2015 and papers therein, ECB (2016), Kindberg-Hanlon and Young (2016), Lewis and Monarch (2016), OECD (2016), Ollivaud and Schwellnus (2015), Timmer et al. (2016), among others, examine the drivers of the global trade slowdown. Amiti et al. (2016) and Hong et al. (2016), on the other hand, examine the drivers of slowing trade in the case of the United States and China, respectively.
} 
and in trading partners, given the global nature of the slowdown. On the structural front, we extend the model of Eaton et al. (2010) by introducing a tradable commodities sector to be able tease out the role of the price and trade dynamics in this sector during the recent slowdown.

The rest of the paper is organized as follows. Section II starts by documenting the evolution of trade growth across various dimensions to establish the key stylized facts about the recent slowdown in trade. Section III discusses the analysis of the trade slowdown based on an empirical model of import demand, in order to quantify the role of economic activity and its composition. Section IV presents a structural multicountry, multisector model of production and trade, which allows us to measure the importance of changes in the composition of demand, and trade costs, among other factors. Section V concludes.

\section{The Slowdown OF Trade Growth: Some Stylized FactS}

An investigation into the evolution of global trade using annual data reveals several key patterns. $^{7}$

- $\quad$ Unlike the great trade collapse, there is a marked difference in how trade has evolved since 2012, depending on whether trade is measured in real or nominal U.S. dollar terms. In real terms, world trade growth has slowed since the end of 2011; in nominal U.S. dollar terms, it has collapsed since the second half of 2014 due to the sharp drop in the price of oil and the strength of the U.S. dollar (Figure 2, panel 1).

- The slowdown in real trade growth has been widespread across countries, both in absolute terms and relative to GDP growth. Compared with the five years leading up to the global financial crisis, growth of goods and services imports during 2012-16 slowed in 142 of 169 countries. When measured relative to GDP growth, the slowdown occurred in 122 countries.

- $\quad$ The contours of the 2012-16 slowdown varied by broad country group and sector. Across country groups, the slowdown was sharp at the outset of the period in advanced economies following the euro area debt crises, but import growth picked up thereafter in line with the modest recovery in those economies. In emerging market and developing economies, the slowdown was initially milder, but became more severe during 2014-15, driven by weaker imports in China and macroeconomic stress in a number of economies.

\footnotetext{
${ }^{7}$ Data on total nominal and real trade for goods and services used in Section II and III are from the IMF's World Economic Outlook Database. Sectoral real trade flows which underpin figure 2, panel 5, are constructed from disaggregated data on trade values and quantities at the Harmonized Commodity Description and Coding Systems (HS) two-digit level from United Nations Commodity Trade Statistics database. See IMF (2016b) for more details.
} 
There is a small recovery in emerging market and developing economies' imports during 2016, which was mostly driven by China. (Figure 2, panels 2 and 3).

- Across sectors, services trade remained more resilient than goods trade, as was the case during the global financial crisis (Figure 2, panel 4). Within goods, the decline in real trade growth was most pronounced for capital goods, followed by primary intermediate goods, and durable consumption goods. Trade in nondurable consumption goods, on the other hand, held up relatively well (Figure 2, panel 5). The sharper slowdown of trade in capital and durable consumption goods (including cars and other nonindustrial transportation equipment), which is a large part of investment expenditures, points to the potential role of economic activity, particularly investment weakness, in holding back global trade growth in recent years.

\section{The Role OF OUTPUT AND ITS COMPOSITION: INSIGHTS FROM AN EMPIRICAL INVESTIGATION}

To gauge the role of economic activity and shifts in its composition in an empirical framework, we examine the historical relationship between import volumes of goods and services and aggregate demand during 1985-2016 to predict a country's import growth from observed fluctuations in its domestic expenditures, exports, and relative prices. We then compare the predicted import growth with actual trade dynamics to assess whether trade has been unusually weak since 2012 given its historical relationship with economic activity.

\section{A. Models of Import Demand}

We begin by estimating a standard import demand model that links import volume growth of goods and services separately to growth in demand, controlling for relative import prices. As discussed in Levchenko, Lewis, and Tesar (2010), an import demand equation, which relates growth in real imports to changes in absorption and relative price levels, can be derived from virtually any international real business cycle model. The exact empirical specification is:

$$
\Delta \ln M_{c, t}=\delta_{c}+\beta_{D, c} \Delta \ln I A D_{c, t}+\beta_{P, c} \Delta \ln P_{c, t}+\varepsilon_{c, t},
$$

in which $M_{c, t}, I A D_{c, t}$, and $P_{c, t}$ denote, respectively, real imports, aggregate demand, and relative import prices of country $c$ in year $t$. Relative import prices are defined as the ratio of the import price deflator to the GDP deflator.

Most studies typically use a country's GDP or domestic demand as a proxy for aggregate demand (absorption). In contrast, the analysis here follows the innovation of Bussière et al (2013) and computes the import-intensity-adjusted aggregate demand (IAD), as a weighted average of traditional aggregate demand components (private consumption, government spending, investment, and exports). This approach explicitly accounts for differences in the import content of the various aggregate demand components and captures the effect of changes 
in the overall strength of economic activity and across its drivers. The latter is especially important in the study of the global trade slowdown. Investment, together with exports, has a particularly rich import content, and it has been weak in many advanced economies still recovering from the global financial and European debt crises. It has also decelerated significantly in many emerging market and developing economies, including in China, which is undergoing a rebalancing of its economy away from investment.

As in Bussière et al (2013), import-intensity-adjusted demand is computed for each country $c$ as:

$$
I A D_{c, t}=C_{c, t}^{\omega_{C}} G_{c, t}^{\omega_{G}} I_{c, t}^{\omega_{I}} X_{c, t}^{\omega_{X}}
$$

in which $\omega_{k}$ is the import content of each of the expenditure components for $k \in\{C, G, I, X\}$, normalized to sum to 1. Import content is computed from the harmonized Eora Multi-Region Input-Output (MRIO) country-specific tables averaged over 1990-2011. ${ }^{8}$ Similar to patterns described by Bussière et al (2013), Table 2 shows that there are significant differences in the usage of imports across aggregate demand components. ${ }^{9}$ Investment and exports have a much richer import content compared with consumption and government spending.

In addition to the measure proposed by Bussière et al (2013), we estimate two alternative models of import demand using: (1) IAD including only the domestic components of aggregate demand (domestic $I A D$ or " $D I A D$ "), and (2) domestic $I A D$ and exports predicted by trading partners" domestic $I A D$ (also referred to as " $D I A D+X$ "). We use these alternative models, since we would like to isolate the drivers of a slowdown in trade, which is widespread across countries. While a single country can take external demand for its goods and services as given, for the world as a whole, only the sum of individual countries' domestic demand determines global import growth.

In the first alternative model, absorption is proxied by import-intensity-adjusted demand

\footnotetext{
${ }^{8}$ Import intensities evolve over time, in response to changing trade costs and international production fragmentation. As the goal of our analysis is to quantify the importance of these other factors in the recent trade slowdown, we use the average import content for each country. It is also worth noting that if import intensity were perfectly measured in each period and the import intensity weights were allowed to vary over time, the model would be able to fully account for the level of imports (although not their growth rates).

${ }^{9}$ See IMF 2015b, Jääskelä and Mathews 2015, Morel 2015, Hong and others 2016, and Martinez-Martin 2016 for further examples of analysis of trade growth based on import-intensity-adjusted aggregate demand, with substantially smaller samples of countries.
} 
using only the domestic components of aggregate demand, namely:

$$
\operatorname{DIAD} D_{c, t}=C_{c, t}^{\omega_{C}} G_{c, t}^{\omega_{G_{1}}} I_{c, t}^{\omega_{I_{1}}}
$$

and the following equation is estimated:

$$
\Delta \ln M_{c, t}=\delta_{\mathrm{c}}+\beta_{D D, \mathrm{c}} \Delta \ln D I A D_{c, t}+\beta_{P, \mathrm{c}} \Delta \ln P_{c, t}+\varepsilon_{\mathrm{c}, \mathrm{t}} .
$$

In the second alternative, absorption is proxied by DIAD and exports, predicted by trading partners' $D I A D, \Delta \widehat{\ln X}_{c, t}$. To compute the latter, we first estimate equation (4) and recover the model-predicted import growth for each country, $\Delta \ln \widehat{M_{c, t}, D I A D}$. We then construct a measure of external demand as the trade-weighted average of partners' $\Delta \ln \widehat{M}_{c, t, D I A D}$ and estimate a model of export demand using this measure as a proxy of the demand for a country's exports:

$$
\Delta \ln X_{c, t}=\delta_{c}^{X}+\beta_{D, c}^{X} \sum_{c, t, p} \Delta \ln \widehat{M_{p, t, D I A D}}+\beta_{P, c}^{X} \Delta \ln P_{c, t}^{X}+\varepsilon_{c, t}^{X}
$$

The procedure then recovers predicted export growth for each country $\Delta \widehat{\ln X}_{c, t}$. Finally, a country's import growth is modeled as:

$$
\Delta \ln M_{c, t}=\delta_{c}+\beta_{D D, c} \Delta \ln D I A D_{c, t}+\beta_{D X, c} \Delta \widehat{\ln X}_{c, t}+\beta_{P, c} \Delta \ln P_{c, t}+\varepsilon_{c, t} .
$$

Tables 3-5 present the results from estimating equations (1), (4), and (6) for growth of real overall imports, as well as separately for goods and services. The period of analysis is 19852016, though data are not available for all countries in all years. As in Bussière et al (2013), the baseline specification assumes that import growth depends only on the contemporaneous growth rate of the explanatory variables; however, the findings discussed in this paper are robust to the inclusion of lags of the dependent and explanatory variables' growth rates to allow for richer dynamics.

For comparison with other studies, we first estimate equation (1) in a panel framework -in other words, where all the countries in the sample are pooled, and the same elasticities of import growth with respect to its determinants are imposed across countries (see columns (1), (5), and (9)). The remaining columns of Tables 3-5 report the mean and the interquartile range of the estimated coefficients from a country-by-country estimation.

The regression results demonstrate that estimating the import demand model separately for each country is noticeably superior to estimation in a panel framework (compare, for example, the R-squared reported in column (2) versus column (1)). This is due to the substantial variation in the income elasticity of imports across countries. On average, advanced economies' imports have higher income elasticity than do those of emerging market and developing 
economies, particularly in the case of goods imports. ${ }^{10}$ In light of this finding, in the remainder of this paper, we discuss results based on a country-by-country estimation of import demand models. Tables 3-5 also highlight the more limited ability of measures of import demand based solely on the domestic components of aggregate demand (columns (3), (7), and (11)) to explain the variation in import growth observed in the data.

\section{B. Results}

Figure 3 depicts the actual evolution of import growth over the 1985-2016 period and the predicted growth based on the three benchmark models described above. For both goods and services, the empirical models' predictions closely track the dynamics of actual import growth until 2012 particularly when predicted values are calculated using the $I A D$ measure based on all four aggregate demand components instead of only those for domestic demand. The figure does reveal, however, that after 2012, the annual growth of real goods imports was consistently lower than any of the model-based benchmarks. For services, the actual and predicted import growth series remain close to each other for the entire period.

To examine more rigorously whether trade growth in the $2012-16$ period is out of the ordinary, we pool the residuals $\widehat{\varepsilon_{c, t}}$ from estimating equations (1), (4), and (6) for each country in the sample and estimate the following specification:

$$
\widehat{\varepsilon_{c, t}}=\theta \operatorname{Const}\left(1-D_{2012-16, t}\right)+\tau \operatorname{Const}\left(D_{2012-16, t}\right)+\zeta_{c, t},
$$

where $D_{2012-16, t}$ is an indicator that takes the value of 1 for $t \in$ $\{2012,2013,2014,2015,2016\}$. The coefficients $\theta$ and $\tau$ capture the average value of the residuals during the 1985-2011 and 2012-16 periods, respectively. Regressions are weighted by countries' nominal import shares (in U.S. dollars) to more accurately capture the deviations from predicted growth for the world as a whole (or groups of countries). ${ }^{11}$

Tables 6 and 7 present the regression results for goods and services real import growth, respectively. Similar to the patterns depicted in Figure 3, Panel 1, for goods imports, the residuals are, on average, significantly less than zero across all samples and specifications in 2012-16, implying that indeed goods import growth is "missing" at the global level during the recent slowdown period (see columns 1-3). The extent of "missing" goods import growth varies across advanced and emerging market and developing economies, with emerging market and developing economies having significantly larger (in absolute value) residuals. According to the baseline specification, which proxies import demand with " $D I A D+X$ "-equation (6), residuals

\footnotetext{
${ }^{10}$ This finding is in line with Slopek (2015) who demonstrates that the shift in relative growth from advanced towards emerging market economies can account for much of the decline in the global trade elasticity in light of the lower income elasticity of trade of the latter.

${ }^{11}$ The findings discussed below are robust to the inclusion of country fixed effects in equation (8) or to clustering the standard errors by country.
} 
in columns (3), (6), and (9) in Table 6-the missing goods import growth amounted to about 1 percentage point in advanced economies, 3 percentage points for emerging market and developing economies, and $13 / 4$ percentage point for the world as a whole (see also Figure 4 ). In the case of services, there is no robust evidence of an unexplained slowdown in import growth during the 2012-16 period for the world as a whole. ${ }^{12}$

The results are also consistent with the time profile of the trade slowdown across countries discussed in Figure 2 in the previous section. In Figure 4, we present the average residuals for the whole sample, as well as for advanced and emerging market economies, separately for each years post 2012. For advanced economies, the unpredicted slowdown in import growth occurred in 2012. Since then, goods import growth has recovered and is close to model-predicted values on average (Figure 4, panel 2). For emerging market and developing economies, the missing goods import growth is larger and has become more pronounced over time (Figure 4, panel 3).

Overall, these results suggest that the strength of economic activity and its composition are unable to fully account for the slowdown in goods import growth beginning in 2012, especially in emerging market and developing economies. But how much of the observed decline in trade growth can be explained by the empirical models discussed above?

To answer this question, we decompose the observed slowdown in goods import growth rates between the period prior to the global financial crisis and during 2012-16. We take both a long view (1985-2007) and a short view (2003-07) of the precrisis period, comparing each of these intervals with 2012-16 to establish what share of the slowdown the empirical model could and could not match. We further allocate the predicted slowdown into the shares attributable to the different aggregate demand components.

Figure 5 and Tables 8-10 present the actual and predicted change in average real goods import growth between 2012-16 and the two benchmark periods using two of the empirical models. The model which relies on all four aggregate demand components - the most relevant from an individual economy's perspective which takes demand from its exports as given - can account for 86 percent of the observed decline in import growth between 2003-07 and 2012-16, and 84 percent of the observed decline in import growth between 1985-2007 and 2012-16. The lion's share of the slowdown can be traced to declines in investment and export growth, especially if we focus on the slowdown relative to 2003-07, when capital spending in many

\footnotetext{
${ }^{12}$ These findings are also robust to controlling for the role of uncertainty, global financial conditions, and financial stress in the economy when analyzing the import demand model residuals. Table 9 present the results from the estimation of equation (8) augmented to include these variables. The finding of unexplained negative real goods import growth residuals during 2012-15 are robust to this alternative specification.
} 
emerging market and developing economies, including China, was growing at an unusually brisk pace.

The importance of changes in export growth as a driver of the slowdown of import growth in individual economies reflects two factors: (1) the tight linkages between a country's imports and exports as production processes become increasingly fragmented across borders, and (2) the globally synchronized weakness in economic growth in recent years. These two factors have contributed to the widespread nature of the trade growth slowdown across countries and have amplified its magnitude.

To trace the role of domestic demand in the global trade slowdown, we break down for each country the share of the decline in import growth accounted for by its exports into: (1) the predicted value of its trading partners' import demand, attributable to domestic demand; (2) the predicted value of its trading partners' import demand, attributable to exports; and (3) a residual portion unaccounted for by the model. Iterating in this fashion, it is possible to fully allocate the global goods import slowdown to domestic demand components and an unpredicted portion as depicted in the middle bar of each panel of Figure 5. This procedure reveals that, for the world as a whole, changes in economic activity can account for over 80 percent of the decline in the global goods import growth rate. The unpredicted portion of the slowdown in global goods import growth is larger than for the average economy, as impediments to trade at the individual country level are compounded in the aggregate. Using the import demand model based on domestic IAD and exports predicted by partners' domestic IAD yields a very similar pattern as revealed in the right bar of the panels in Figure 5 and columns (9)-(15) of Tables 8-10.

There are important differences in the empirical models' ability to predict the slowdown in trade across broad country groups. In advanced economies, over 90 percent of the decline in import growth in 2012-16 relative to 2003-07 can be ascribed to changes in economic activity. In emerging market and developing economies, the empirical model can predict a notably smaller share of the trade slowdown., suggesting that other factors are also at play.

Ultimately, the empirical exercise reveals that the slowdown in goods import growth during 2012-16 is not just a symptom of weak activity. Over 80 percent of the global trade slowdown can be traced to the combined effect of slower overall growth, a change in the composition of economic activity away from more import-intensive components - namely, investment-, and the synchronized nature of the growth slowdown across countries, which may be in part effected via trade. However, at the global level, goods import growth rates during 2012-16 have fallen short by about $13 / 4$ percentage points on average relative to what would be expected based on the historical relationship between trade flows and economic activity. This is not a trivial amount: the level of real global goods trade would have been 8 percent higher in 2016 had it not been for this missing trade growth.

The empirical approach described above is well established in the literature, but carries two important caveats. First, as previously discussed, it focuses narrowly on only one side of the 
relationship between economic activity and trade: the link from the former to the latter. Other factors can simultaneously affect economic activity and trade, in particular, trade policies. Not taking these into account would likely lead to an upward bias in the estimated role of economic activity in predicting trade flows. In an extended robustness check, we establish that this bias is likely small. ${ }^{13}$

Second, as a partial equilibrium analysis - the empirical model takes each country's external demand as given-it is insufficient on its own to analyze a synchronized trade slowdown across many countries. While we have presented alternative specification that overcome this limitation, an even more suitable way to capture the synchronized nature of the trade slowdown is through the lens, of a multicountry general equilibrium structural model. The general equilibrium approach also allows for an endogenous response of the level of economic activity and output to changes in trade patterns and trade costs through their effect on intermediate and consumption goods' prices, thus addressing partially the first limitation of the empirical approach as well. ${ }^{14}$

\section{The Role OF DEMAND COMPOSITION AND TRADE COSTS: InSIGHTS FROM A STRUCTURAL INVESTIGATION}

In this section, we examine the slowdown in the growth of trade in goods relative to GDP growth in nominal terms by adapting the multisector, multicountry, static model of production and trade in Eaton et al (2010). ${ }^{15}$ Since this is a general equilibrium model, which endogenously computes equilibrium wages and prices, the main object of interest is nominal import growth in relation to GDP growth.

\section{A. Framework}

In our framework, countries trade to exploit their comparative advantage in goods production. However, international trade is costly: it involves transportation costs and man-made trade barriers, such as tariffs. Countries weigh these trade-related costs against the efficiency

\footnotetext{
${ }^{13}$ To correct for the potential for role of trade policies in shaping economic activity, we first purge aggregate demand components of the effect of trade policies before constructing our measure of IAD. Doing so yields slightly larger "missing" trade growth during 2012-16. For the average economy, the share of the decline in import growth predicted by changes in economic activity - by construction orthogonal to trade policies - and relative prices is 83 percent, compared to the 86 percent using the baseline specification.

${ }^{14}$ As is the case with most general equilibrium models of trade, certain channels through which trade affects output, for example, the dynamic productivity gains from greater trade openness, are not captured.

15 This model incorporates the canonical Ricardian trade model of Eaton and Kortum (2002). Eaton et al (2016) extend the static model of their 2010 work to explicitly model the role of investment in a dynamic framework. However, the dynamic version of the model has a heavier data and computational requirement, making its estimation for a large number of emerging market economies not feasible for this study.
} 
gains from trade to determine whether and how much to produce, export, and import. The model also includes a rich input-output structure allowing the output from each sector-durable, nondurable manufacturing, and commodities and a residual sector that mostly includes nontradables - to be used as an input to other sectors.

One important modification to the framework of Eaton et al (2010) is the inclusion of a fourth sector composed of commodities in addition to two manufacturing sectors (producing durable and nondurable goods) and the residual sector, which covers primarily services. ${ }^{16}$ This is an essential addition in light of recent price shifts in this sector, which affect the ratio of trade growth to GDP growth. ${ }^{17}$ However, the model does not separate investment from consumption, and the findings on the role of demand composition should be interpreted in light of this limitation.

According to the model, observed trade dynamics can be attributed to changes in four specific factors, or "wedges": (1) composition of demand; (2) trade costs (or frictions); (3) productivity; and (4) trade deficits, following the business cycle accounting approach of Chari, Kehoe, and McGrattan (2007). These time-varying wedges act as shocks to preferences, cost of trade, productivity, and trade deficits, thereby influencing agents' economic decisions, including whether to trade. When the observed patterns of sectoral trade, production, and prices are analyzed through the lens of the model, the model endogenously allocates changes in actual trade flows to these four wedges so that the implied trade dynamics match those in the data exactly. The four factors are sector and country specific and are identified within the framework as follows:

- $\quad$ The demand composition wedge captures changes in the share of a sector's output in total final demand. For example, if weak investment reduces demand for durable manufactured goods disproportionately more than the demand for other goods, changes in trade flows will be attributed to this wedge.

- $\quad$ The trade costs wedge accounts for changes in preferences between domesticallyproduced and imported goods that are not due to relative price changes. For example, if prices in all countries remain fixed, but a country consumes more domestically-produced durables than imported durables, this would be attributed to rising trade costs. These

\footnotetext{
${ }^{16}$ Sectors are aggregated along the lines of Eaton et al (2010) with the exception that (i) mining and quarrying, and (ii) coke, refined petroleum products, and nuclear fuel are stripped out from the residual services sector and used to quantify the commodities sector.

${ }^{17}$ In this Ricardian model of trade, trade in commodities occurs as a result of differences in the efficiency of production. This can be mapped to the real world-for example, oil importers have reservoirs deep underground and extraction is more inefficient than for oil exporters.
} 
trade costs may include tariffs, subsidies for domestic production, nontariff barriers, cross-border transportation costs, and so forth. ${ }^{18}$

- $\quad$ The productivity wedge reflects countries' comparative advantage. As a country becomes more productive in a particular sector, it exports more output from this sector to its trading partners and consumes more of this sector's output domestically.

- $\quad$ The trade deficit wedge is necessary to ensure that the model can perfectly match imports and exports for countries that run trade deficits or surpluses.

Many of the key hypotheses about the causes of the slowdown in global trade relative to GDP can be mapped to these factors. A slowdown in trade growth, which mostly reflects shifts in the composition of economic activity, will be captured in the demand composition wedge. On the other hand, if the erection of trade barriers or a slower pace of trade liberalization underpins the slowdown, the model would attribute this to a rise in the trade cost wedge. By generating counterfactual scenarios in which only one factor is allowed to change, the model can quantify the role of these wedges in the current trade slowdown in a general equilibrium setting. For example, in the scenario with only the demand composition wedge active, the model allows the demand composition to change as observed in the data but keeps trade costs, productivity, and trade deficits constant. For the purposes of this paper, only the results of the counterfactual scenarios for the first two wedges (demand composition and trade costs) are presented. ${ }^{19}$

Production and trade in the commodity sector are modeled as for the manufacturing sectors, and so the functional forms of the equations for the latter can be applied to the former. This means there is an additional set of equilibrium conditions that serve to pin down prices, trade shares, and spending in the commodity sector. ${ }^{20}$ Using the notation of Eaton and others (2010), necessary modifications to the equations provided therein are listed below.

- $\quad$ Sets of all sectors and tradable sectors are redefined to include commodities, $\Omega=$ $\{D, N, C, S\}$ and $\Omega_{M}=\{D, N, C\}$, respectively where $C$ denotes the index for the

\footnotetext{
${ }^{18}$ The model does not feature any nominal rigidities or variations in the length of global value chains. This implies that observed fluctuations in trade flows due to these two factors will be imperfectly attributed to one of the four wedges. For example, the recent depreciation of stressed emerging market currencies appears to have boosted the trade cost wedge as trade values declined more than domestic absorption and production in U.S. dollars due to incomplete exchange rate pass-through. Similarly, changes in global value chain growth also tend to be absorbed by the trade cost wedge as exemplified by significant declines in measured trade costs for Vietnam.

${ }^{19}$ The trade deficit wedge played a negligible role during the recent trade slowdown. The productivity wedge exhibits some interesting dynamics, but they can be ascribed mostly to the recent supply-side-induced price changes in the commodity sector.

${ }^{20}$ The modified system of equations is available on request from the authors.
} 
commodities sector. This modification introduces additional equilibrium conditions to pin down prices, trade shares, and spending in the commodities sector.

- $\quad$ The market clearing condition for each country is rewritten to sum across all sectors including commodities:

$$
Y_{i}^{D}+Y_{i}^{N}+Y_{i}^{C}=\sum_{l \in \Omega_{M}} \sum_{n=1}^{I} \pi_{n i}^{l} X_{n}^{l}
$$

which equalizes country $i$ 's gross output (on the left) to global spending on this county's tradable output (on the right).

\section{B. Data, Solution, and Calibration}

The analysis uses annual sectoral data on production, bilateral trade, and producer prices for 2003-16 to apply the accounting procedure for 17 advanced and 17 emerging market and developing economies (Table 1), thus extending both the geographical and temporal coverage of Eaton et al (2010). The analysis thus accounts for 75 percent of world trade. Numerous data sources were spliced to obtain the necessary time coverage through 2016. In 2016, four of those countries are excluded (Austria, Finland, Thailand, and Vietnam) due to lack of disaggregated trade data at the time of the analysis.

For sectoral gross production, data through 2009 or 2011 are from the Organisation for Economic Co-operation and Development (OECD) Structural Analysis Database, where available. For countries not included in this database, World KLEMS, OECD Input-Output Tables, and Eora Multi-Region Input-Output (MRIO) database are used. For most advanced economies, national sources provide data through 2014, which are used to extrapolate forward the data from the multinational sources. Remaining gaps in the data are filled using the growth rates of sectoral industrial production and producer price indices. These indices tend to be more disaggregated than the four sectors considered in the analysis. The weights for this aggregation are based on the latest available production data. For the bilateral sectoral import and export flows, data for Belgium and the Philippines are rescaled such that total import and exports from the United Nations Commodity Trade Statistics database match those from the IMF World Economic Outlook database to adjust for the inclusion of re-exports in the former.

The solution procedure utilizes the "exact hat algebra" developed by Dekle, Eaton, and Kortum (2008). The key endogenous variables (wages, spending, prices, trade shares) are expressed as a ratio of their end-of-period to beginning-of-period value (gross changes form) given values for the four wedges. Next, the wedges are solved for in a way that the variation in the key endogenous variables implied by the model's equations matches their variation in the actual data. Counterfactual scenarios - in which certain wedges are turned on and off-rely on the first step of this procedure, in which outcomes are pinned down taking the values of wedges 
as given. Since the framework is static, the solution procedure is run separately for consecutive year-pairs by feeding in data for two years at a time.

Calibrated parameters include the input-output coefficients, value-added coefficients, and the inverse measure of the dispersion of inefficiencies that governs the strength of comparative advantage in each sector. Following Eaton and others 2010, the inverse measure of the dispersion of inefficiencies is set to 2 and assumed to be the same for all sectors. The literature's estimates for this parameter vary greatly. Setting it to equal 8 as in Eaton and Kortum (2002) yields similar results. The remaining parameters are pinned down using the 2011 OECD Trade in Value database. The only exceptions to this are the value-added coefficients for the "rest of the world" category consisting of countries outside of the sample. Those coefficients are set so as to match the exports-to-production ratio of each sector in the data. The exports-to-production ratios are calculated by aggregating exports and production in 2013 for all countries in the Eora MRIO database excluding the 34 countries used in the exercise.

\section{Results}

Comparing the results from the two counterfactual scenarios with the actual data on the gross growth of nominal imports-to-GDP ratio for 2003-16 (Figure 6, panels 1, 3, and 5) yields the following insights:

- $\quad$ During 2003-07, nominal goods trade grew faster relative to GDP because of both shifts in the composition of demand and reduced trade costs. In advanced economies, these two factors were about equal in importance; in emerging market and developing economies, falling trade costs took a leading role, particularly for China, which is consistent with its accession to the World Trade Organization in 2001.

- The 2012-16 slowdown in the growth of the nominal goods import-to-GDP ratio was characterized by a shift in demand toward nontradables and by a shift within tradables toward nondurable manufactured goods. For the world, the expenditure shares of all three tradable sectors declined; the share of commodities fell more than others given that sector's price declines. The performance in the last two years in the ratio of nominal import growth to GDP growth was mostly linked to the shifts in commodity prices.

- $\quad$ The model attributes that largely to wedges in the commodity sector. However, other wedges played a role, too, with their relative contribution varying across countries. For example, China stands out in terms of a rise in trade costs. Although it is difficult to pinpoint the driver of this finding, it may be indicative of the flattening of global value chains. Brazil experienced a significant decline in the share of durable manufacturing goods in its expenditures, which depressed the growth of imports.

Comparing results of the alternative scenarios for 2003-07 with those for 2012-16 reveals that changes in demand composition alone accounted for almost 60 percent of the slowdown in world trade growth relative to GDP growth (Figure 6, panels 2, 4, and 6). In 
addition, the shift in the composition of demand has been more important in advanced economies than in emerging market and developing economies. For the world, trade costs also played a nonnegligible role: the model attributes close to 25 percent of the slowdown in the growth of nominal imports-to-GDP ratio to changes in this factor. Reductions in trade costs boosted trade in 2003-07, while their pace of decline fell considerably in 2012-16. When combined - that is, when changes in the composition of demand and in trade costs are allowed to shape trade flows simultaneously - the model can account for close to 80 percent of the slowdown. ${ }^{21}$

Studying the values for the demand composition wedges, i.e., shares in final demand, by sector reveals the flattening of the share of durable manufacturing coupled with a steady decline in the share of commodities during the slowdown period (Figure 7, panel 1). While the share of durable manufacturing sector continued to rise during this period in emerging market and developing economies, this rise took place at a much slower rate than the pre global financial crisis benchmark of 2003-07, when investment was growing at an unusually fast rate in these countries (Figure 7, panel 3). The sum of all three tradable sectors' shares decreased modestly by $1 / 2$ percentage points during the slowdown after increasing by almost four percentage points prior to the crisis period. These results provide further evidence to support our finding that the fast growth of investment provided a strong impetus to trade prior to the crisis and this impetus vanished post 2012 .

\section{Conclusions}

Despite their significant differences, the two analytical approaches deliver a consistent message. The global slowdown in trade reflects to a significant extent, but not entirely, the weakness of the overall economic environment and compositional shifts in activity. Empirical analysis suggests that, for the world as a whole, over 80 percent of the decline in trade growth since 2012 relative to $2003-07$ can be predicted by weaker economic activity, most notably subdued investment growth. While the empirical estimate may overstate the role of output given the feedback effects of trade policy and trade on growth, a general equilibrium framework suggests that changes in the composition of demand account for about 60 percent of the slowdown in the growth rate of nominal imports relative to GDP. According to both methodologies, demand composition shifts have played a larger role in the slowdown in advanced economies' trade, relative to that in emerging market and developing economies. And, finally, both the structural model and the reduced-form approach suggest a role for other factors, including trade costs, in the observed slowdown in trade.

What can be done so that trade can play its role in helping promote productivity and growth in the context of slow and fragile global activity? First, this paper's findings suggest that

\footnotetext{
${ }^{21}$ Adding up the results under four counterfactual scenarios, each featuring a different wedge, does not necessarily yield the scenario containing all wedges at the same time. The wedges can amplify or dampen each other when they are present simultaneously, so that the sum of the fraction of the data they can account for individually can be greater or less than one.
} 
much of the trade slowdown appears to be a symptom of the many forces that are holding back growth across countries, possibly including the slower pace of reduction in trade costs and slow trade growth itself. Addressing these constraints to growth and, in particular, investment should lie at the heart of the policy response for improving the health of the global economy, which would strengthen trade as a by-product. Second, this paper's findings also suggest that trade policies, which shape the costs of the international exchange of goods and services, are still relevant. With other factors, notably weak investment, already weighing on trade, resisting all forms of protectionism and reviving the process of trade liberalization to dismantle remaining trade barriers, would provide much-needed support for trade growth, including through possibly kicking-off a new round of global value chain development. 
Figure 1. World Real Trade and GDP Growth in Historical Perspective (Percent)
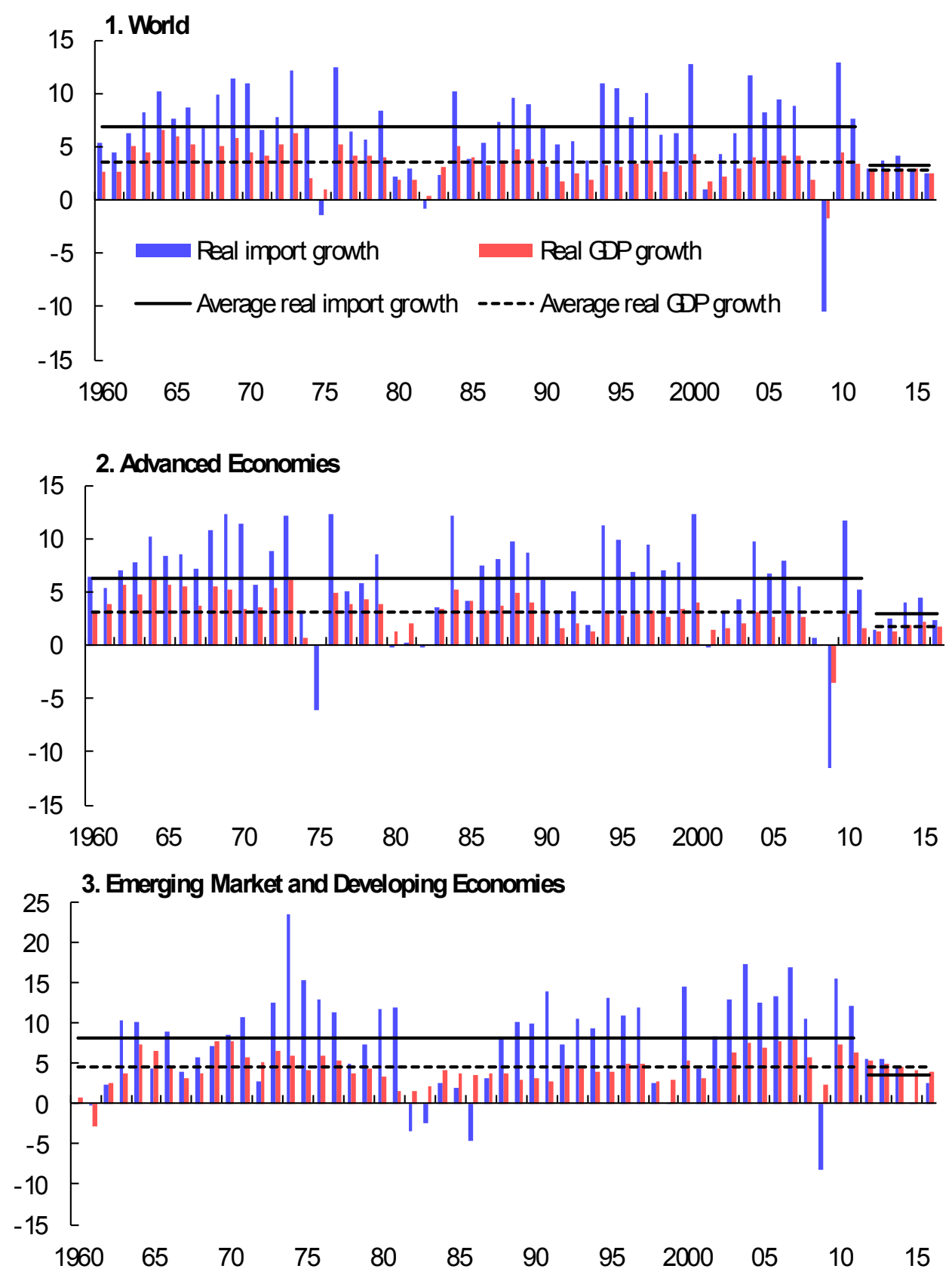

Source: IMF staff calculations.

Note: Imports include goods and services. The charts are based on an unbalanced sample of countries comprising 100 countries in 1960 and 189 in 2016. Annual aggregate import (GDP) growth is calculated as the weighted average of country-specific real import (GDP) growth rates, where nominal import (GDPat market exchange rates) shares are the weights used. 
Figure 2. Trade in Values, Volumes, Across Country Groups, and Types of Products (Percent)

\section{Goods and Services Import Gronth}

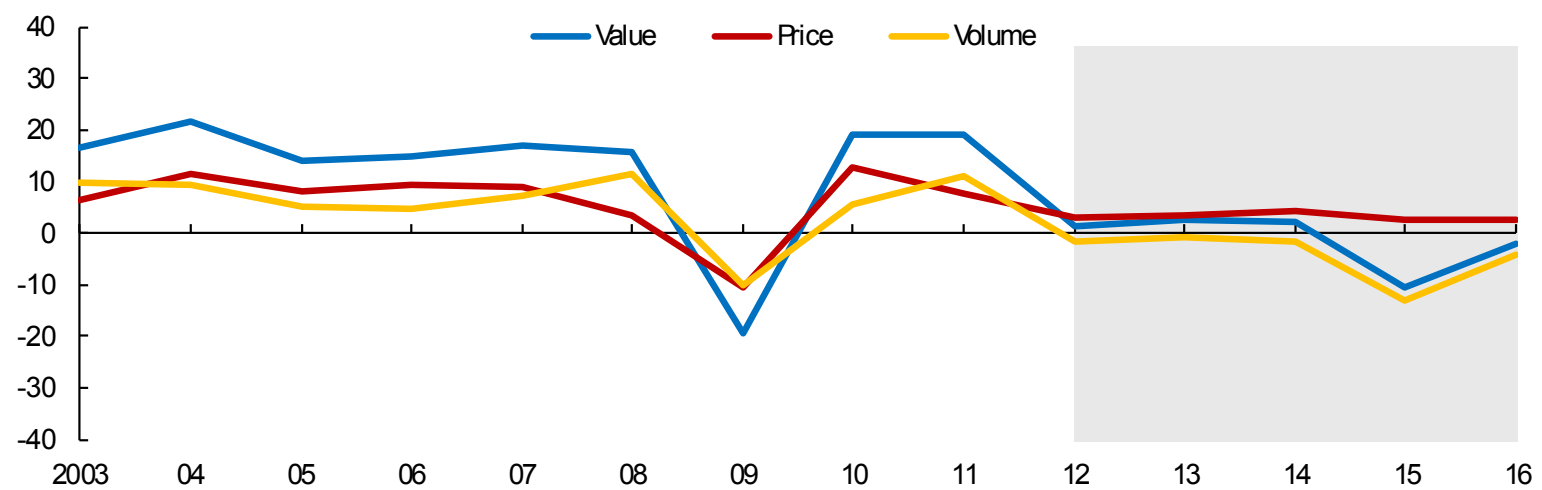

\section{Real Import Growth}

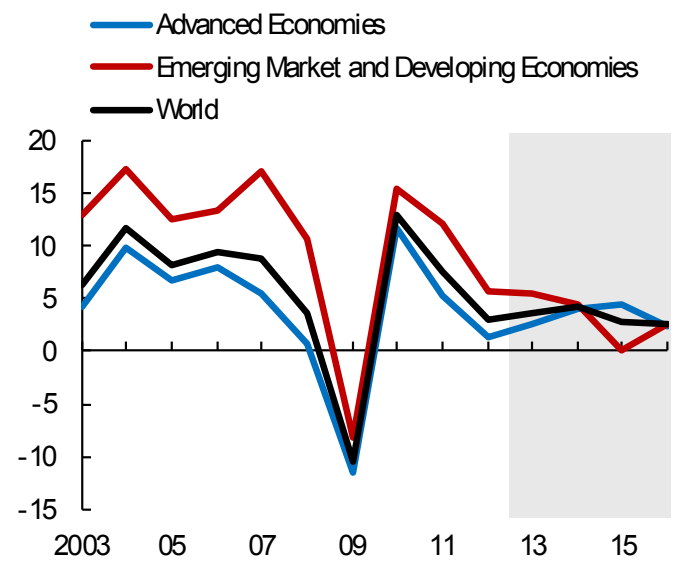

\section{World Real Goods and Senices Import Growth}

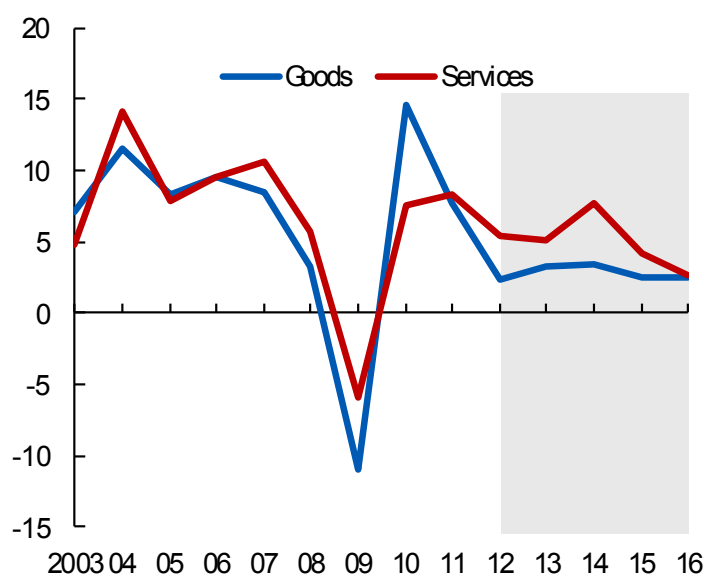

3. Contributions to Real Import Growth

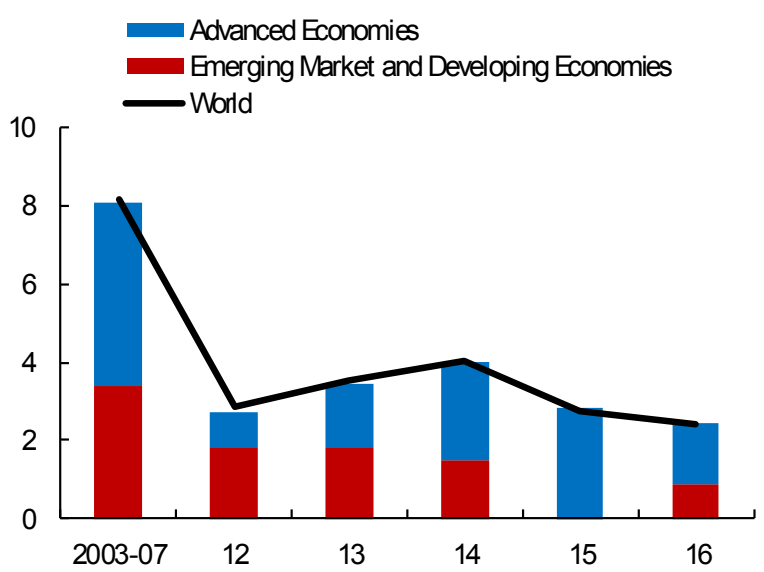

\section{Real Import Growth of Different Product Groups}

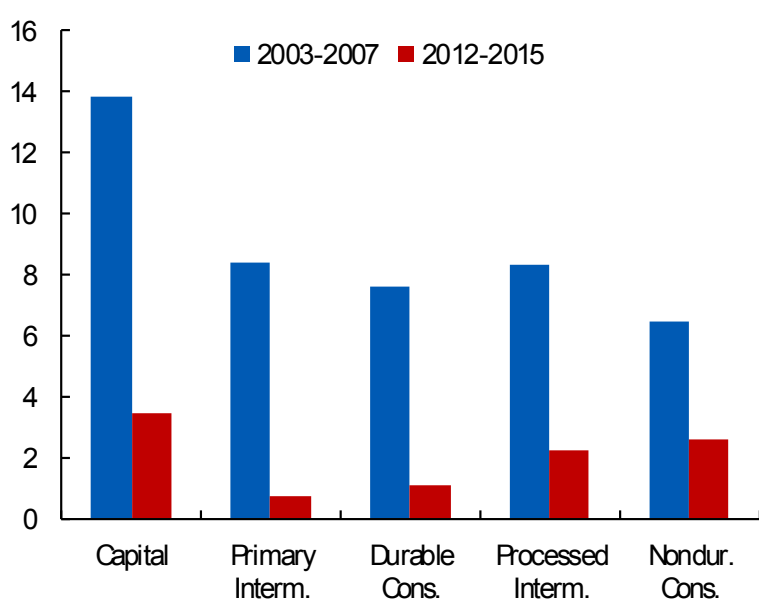


Figure 3. Empirical Model: Actual and Predicted Growth of Real Goods and Services Imports, Full Sample (Percent)

-Actual Import Growth

- Predicted import growth based on domestic import-intensity-adjusted demand

- Predicted import growth based on import-intensity-adjusted demand

- Predicted import growth based on domestic and partners' domestic import-intensity-adjusted demand
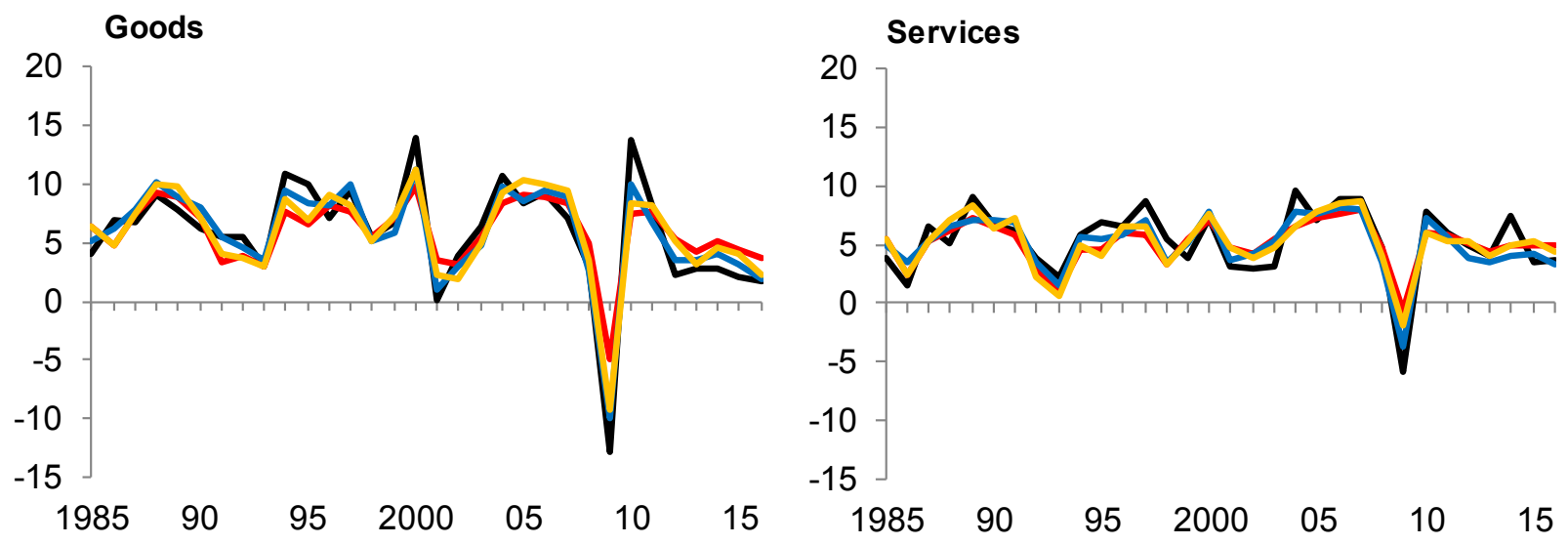
Figure 4. Empirical Model: Difference Between Actual and Predicted Growth of Real Goods Imports

(Percent)

- Predicted based on domestic import-intensity-adjusted demand

- Predicted on import-intensity-adjusted demand

Predicted based on domestic and partners' import-intensityadiusted demand
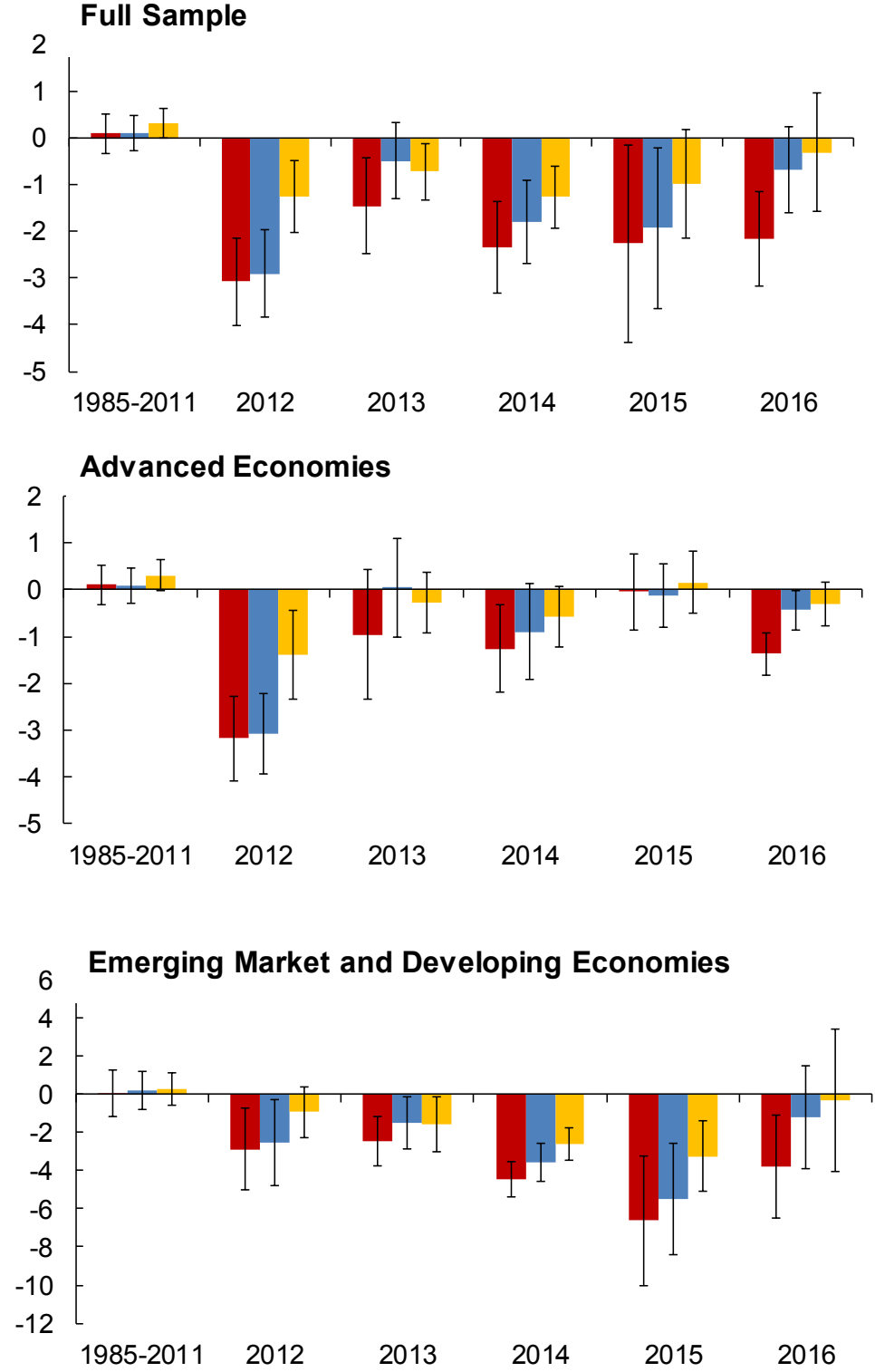

Source: IMF staff calculations.

Notes: Bars display the average residuals, weighted by import shares, from an import demand model, estimated country-by-country, linking real import growth to growth in import-intensity-adjusted demand and relative import prices. Black markers denote the 90 percent confidence interval. 
Figure 5. Empirical Model: Decomposing the Slowdown in Real Goods Imports Growth (Percentage points)

- Predicted by Consumption and Relative Prices

- Predicted by Investment

Predicted by Exports

- Predicted by own and partners' domestic import-intensity-adjusted demand

- Unexplained

\section{Full Sample}

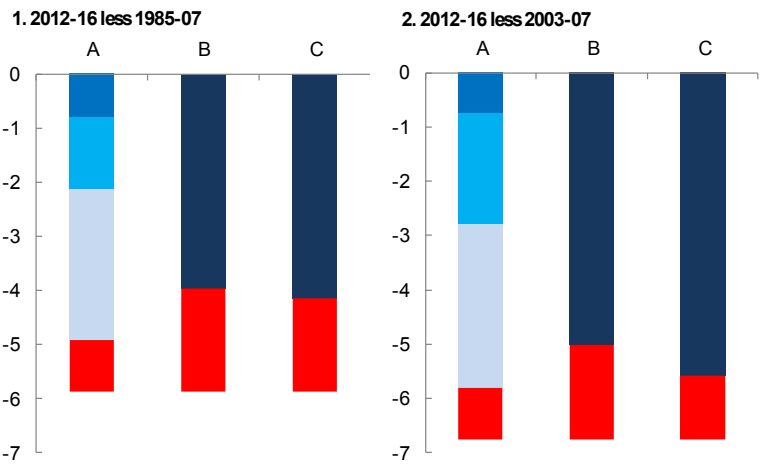

Advanced Economies

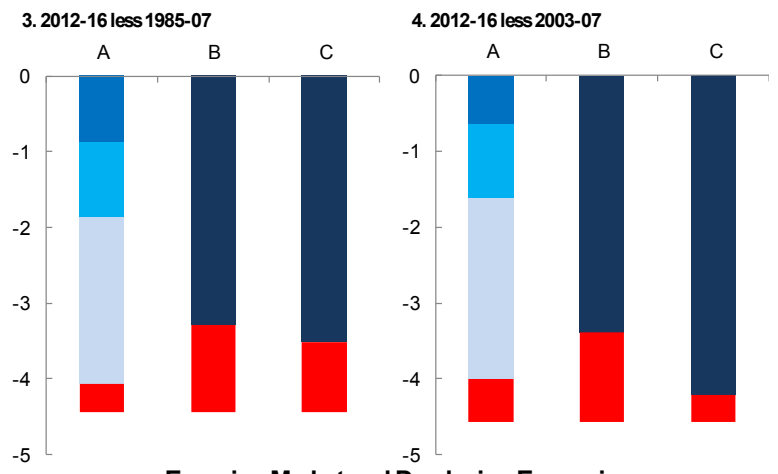

Emerging Market and Developing Economies

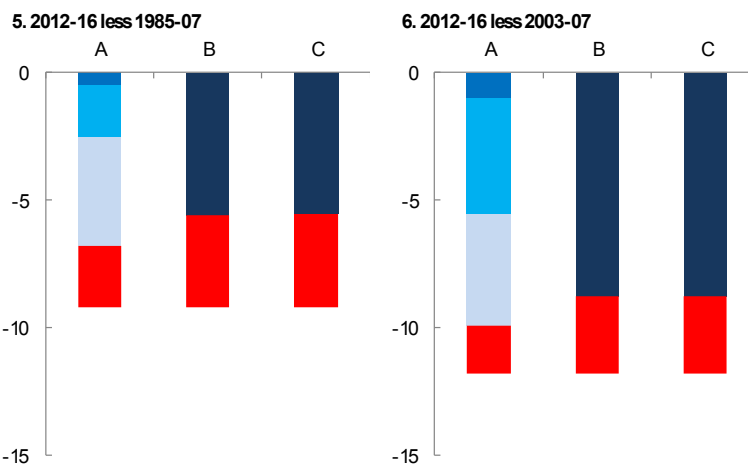

Source: IMF staff calculations

Notes: Bar A decomposes the difference in average real goods import growth between the two periods into portions predicted by consumption and relative prices, investment, exports, and an unpredicted residual. Bar B apportions the component predicted by exports into what can and cannot be predicted by domestic demand from trading partners, using an iterative procedure. Bar Cdecomposes the, difference into the sum of domestic demand and external demand predicted by trading partners
domestic demand. 
Figure 6. Structural Model: Actual and Model Implied Evolution of Nominal Import-toGDP Ratio

Gross Growth of Nominal Imports-to-GDP Ratio

1. World

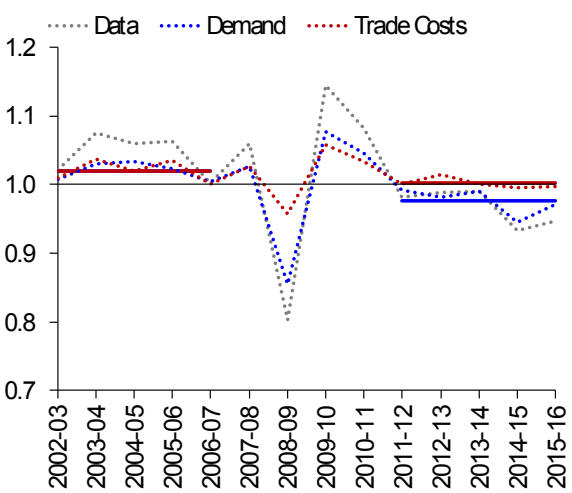

Change in the Gross Growth of Nominal Imports-toGDP Ratio between 2012-16 and 2003-07

(Percentage points)

2. World

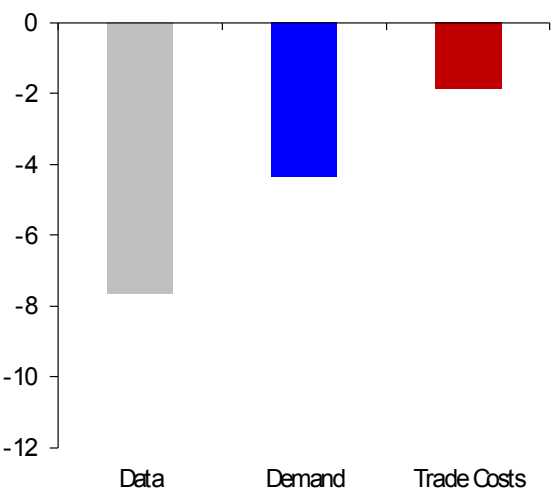

4. Advanced Economies

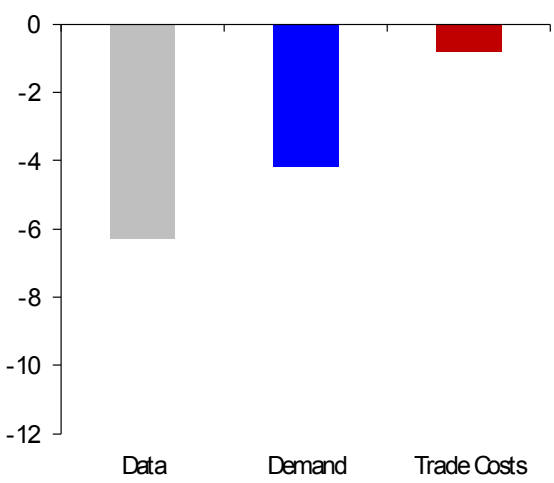

6. Emerging Market and Developing Economies

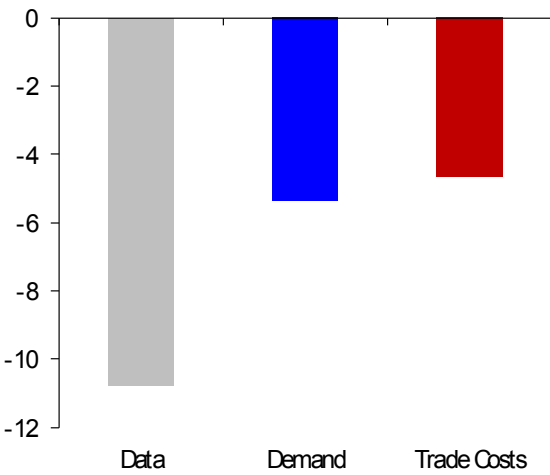

3. Advanced Economies

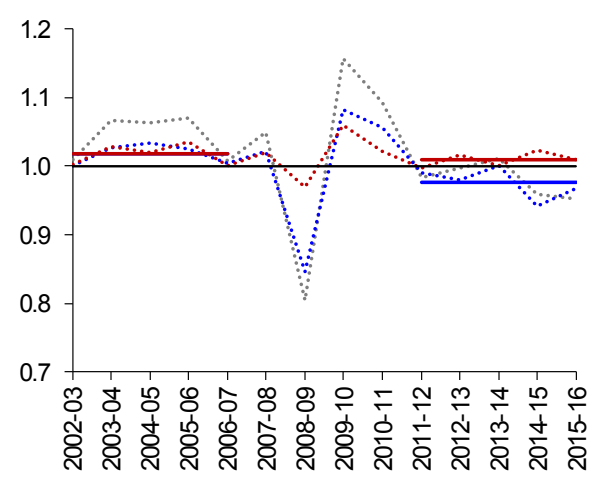

5. Emerging Market and Developing Economies

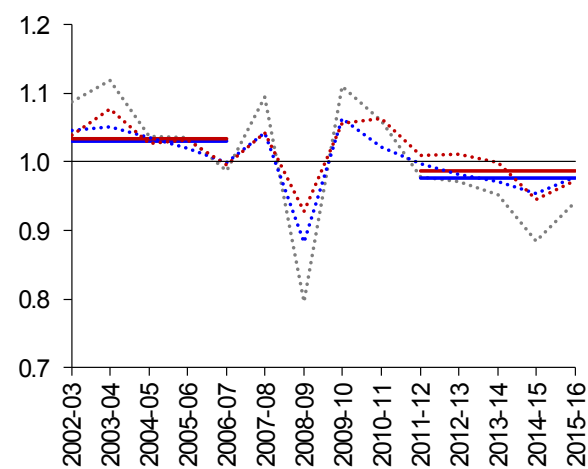

Source: IMF staff calculations.

Notes: Actual and simulated lines in Panels 1, 3, and 5 display the ratio of gross growth of nominal goods imports to gross growth of nominal world GDP, $\left(M_{t} / M_{t-1}\right) /\left(Y_{t} / Y_{t-1}\right)$, and their period averages (solid lines). A value of one indicates that nominal imports and GDP grow at the same rate. The simulated effect of demand composition and trade costs are obtained through counterfactual exercises in which only the corresponding wedge is allowed to operate, holding all other factors affecting production and trade constant. Adecline in trade costs corresponds to an increase in the depicted trade wedge as it boosts model implied trade values. Bars in Panels 2, 4, and 6 display the difference in the average growth of the importto-GDP ratio described above between 2003-07 and 2012-16 implied by: (i) the data; (ii) by the model with the demand composition wedge only, and (iii by the model with the trade cost wedge only, that is, the differences in the period averages depicted in Panels 1, 3 and 5. 
Figure 7. Structural Model: Demand Composition Wedges

(Share)

-Durables - Nbndurables Commodities

\section{World}

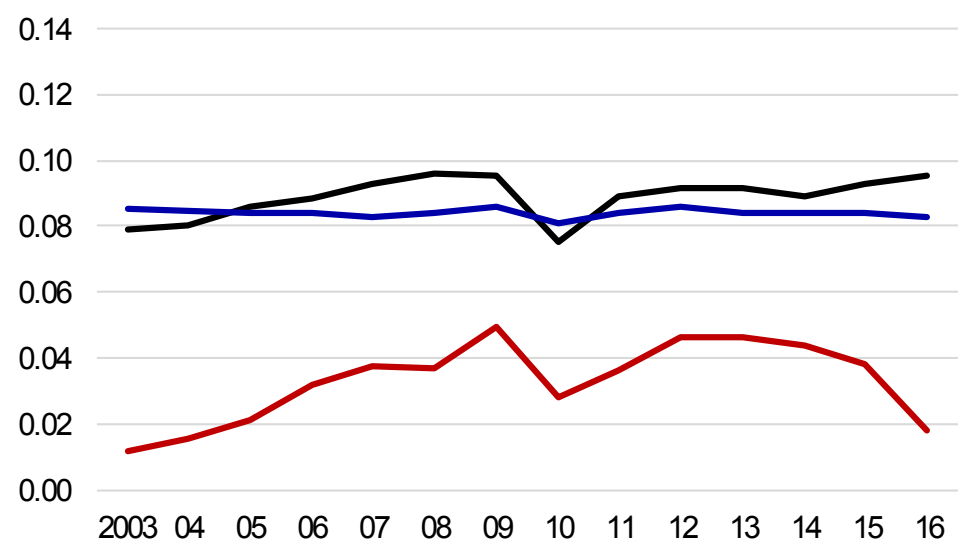

\section{Advanced Economies}

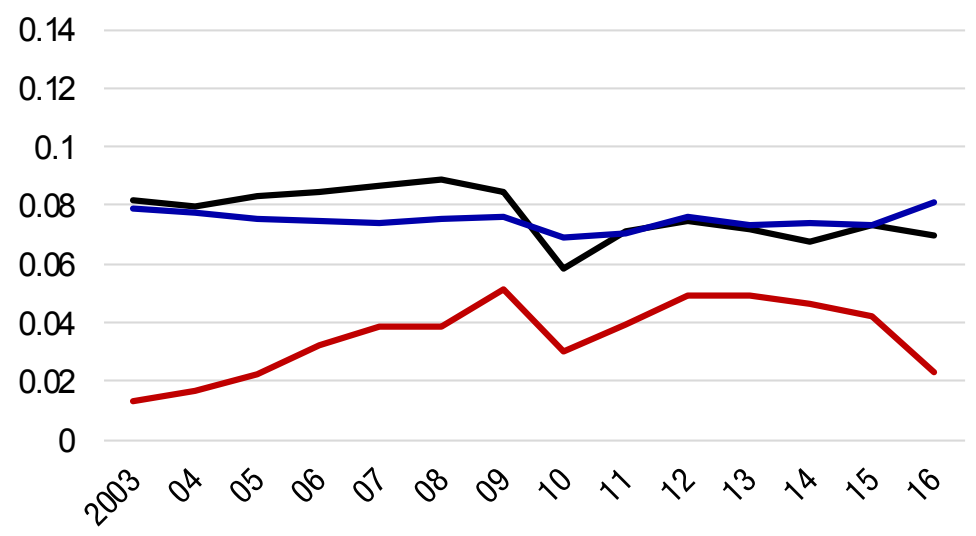

\section{Emerging Market and Developing Economies}

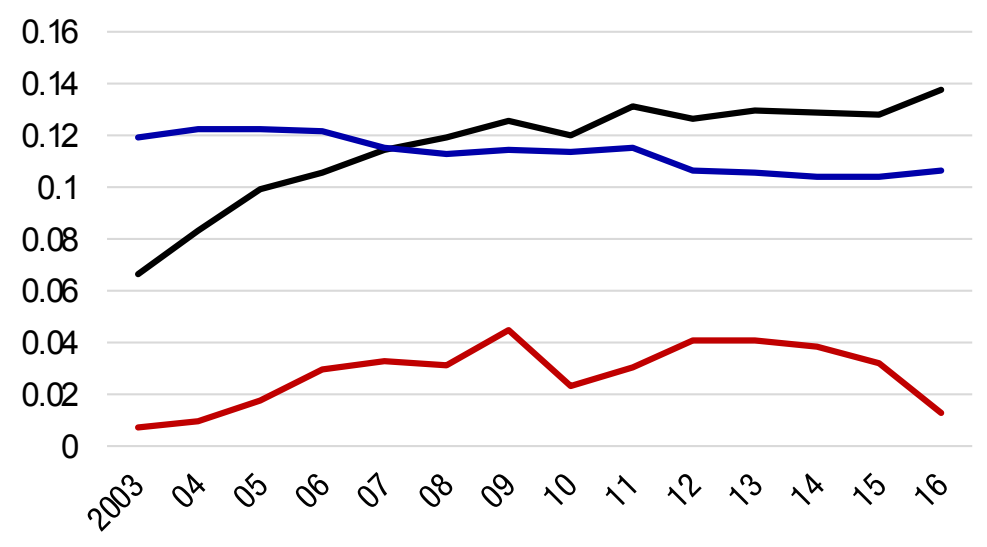

Source: IMF staff calculations.

Notes: Demand composition wedges, that is, shares in final demand, as measured by the structural model are plotted for the three tradable sectors. 
Table 1. Sample of Economies by Exercise

\begin{tabular}{|c|c|c|}
\hline \multirow{2}{*}{ Economies $^{1}$} & \multicolumn{2}{|c|}{ Exercise $^{2}$} \\
\hline & I & II \\
\hline $\begin{array}{l}\text { Australia*, Argentina, Austria*, Belgium*, Brazil, Canada*, Chile, China, Colombia, Czech Republic*, Denmark*, France*, } \\
\text { Finland", Germany*, Hungary, India, Indonesia, Italy*, Japan*, Korea*, Malaysia, Mexico, Norway*, Philippines, Poland, } \\
\text { Russia, South Africa, Spain*, Sweden*, Thailand, Turkey, United Kingdom*, United States*, Vetnam }\end{array}$ & $x$ & $x$ \\
\hline
\end{tabular}

Albania, Algeria, Angola, Antigua and Barbuda, Armenia, Bahamas, Bahrain, Barbados, Belarus, Benin, Bolivia, Bosnia and Herzegovina, Botswana, Brunei Darussalam, Burkina Faso, Burundi, Cambodia, Cameroon, Cape Verde, Central African Republic, Chad, Democratic Republic of the Congo, Republic of Congo, Côte d'Ivoire, Oroatia, Diibouti, Dominican Republic, Ecuador, Egypt, 日 Salvador, Eitrea, Estonia*, Ehiopia, Gabon, Gambia, Ghana, Greece*, Guinea, Haiti, Honduras, Hong Kong SAR*, lœeland, Iran, Ireland*, Israel*, Jordan, Kenya, Lebanon, Lesotho, Kazakhstan, Lithuania*, Luxembourg*, Madagascar, Malawi, Maldives, Mali, Mauritius, Moldova, Mongolia, Republic of Montenegro, Morocco, Mozambique, Myanmar, Namibia, Netherlands*, New Zealand*, Nger, Oman, Pakistan, Papua New Guinea, Peru, Portugal*, Romania, Rwanda, Saudi Arabia, Senegal, Serbia, Seychelles, Sierra Leone, Singapore*, Slovak Republic*, Slovenia*, Si Lanka, Suriname, Swaziland, Switzerland*, Syria, Taiwan Province of China*, Tanzania, Togo, Trinidad and Tobago, Uganda, Ukraine, United Arab Emirates, Utuguay, Venezuela, Yemen, Zambia.

Nbtes: ${ }^{1}$ Asterisk (*) denotes advanced economies as classified by the IMF, World Economic Outlook.

${ }^{2}$ Analytical exercises performed in the chapter: I = Import Demand Model; and II = Structural Model.

\section{Table 2. Import C ontent of Aggregate Demand Components}

\begin{tabular}{lcccc}
\hline & Mean & Median & 25th Percentile & 75th Percentile \\
\cline { 2 - 5 } & $(1)$ & $(2)$ & $(3)$ & $(4)$ \\
\hline Consumption & 23.3 & 20.7 & 13.7 & 27.7 \\
Government Spending & 14.9 & 12.1 & 8.8 & 17.4 \\
Investment & 29.6 & 26.2 & 19.0 & 35.7 \\
Exports & 31.8 & 26.2 & 14.7 & 43.0 \\
\hline
\end{tabular}

Sources: E ora Multi-Region Input-0 utput database; and IMF staff calculations.

Note: The table reports the average, median, 25th percentile, and 75th percentile of the import content of the four components of aggregate demand across the 150 countries included in the sample. For each country, the import content refers to the average import content over 1990-2011. See Bussière and others 2013 for the exact definition of import content and its computation from national input-output tables. 


\section{Table 3. Empirical Model of R eal Imports of Goods and Services}

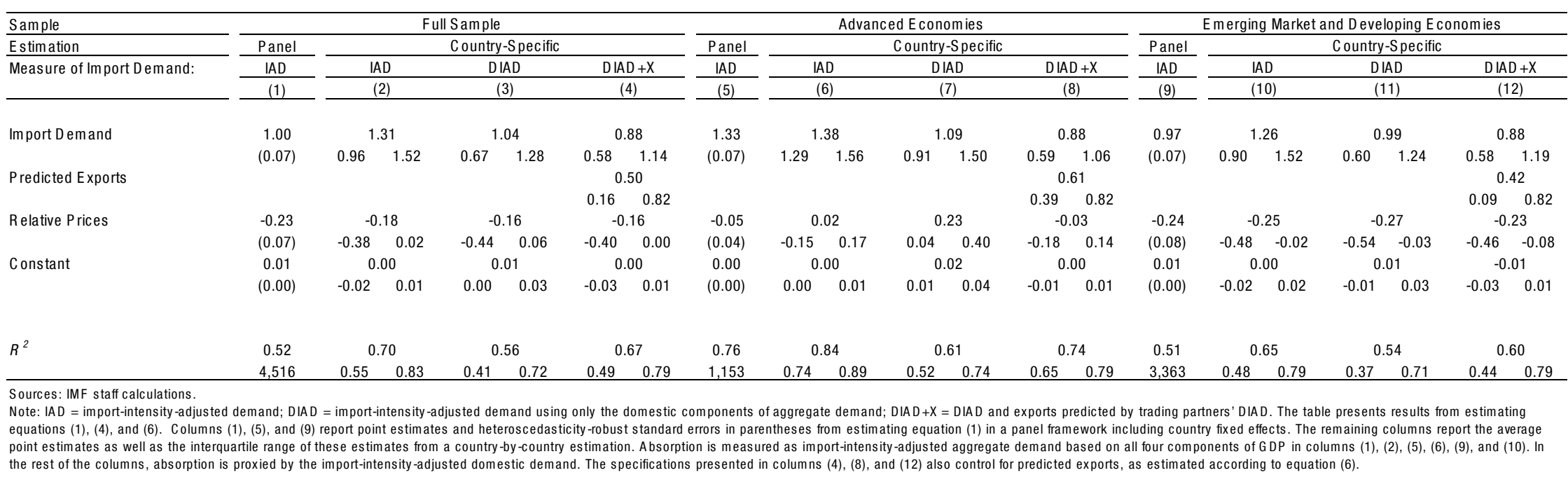

Table 4. Empirical Model of Real Imports of Goods

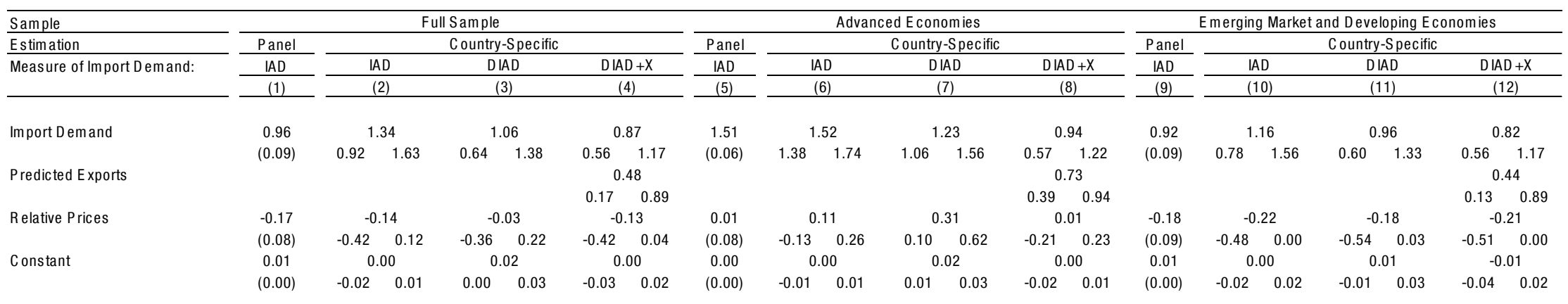

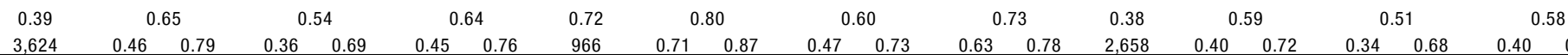

Source: IMF staff calculations. equations (1), (4), and (6). Columns (1), (5), and (9) report point estimates and heteroscedasticity-robust standard errors in parentheses from estimating equation (1) in a panel framework including country fixed effects. The remaining columns report the average point estimates as well as the interquartile range of these estimates from a country-by-country estimation. Absorption is measured as import-intensity-adjusted aggregate demand based on all four components of $G D P$ in columns (1), (2), (5), (6), (9), and (10). In the rest of the columns, absorption is proxied by the import-intensity-adjusted domestic demand. The specifications presented in columns (4), (8), and (12) also control for predicted exports, as estimated according to equation (6). 
Table 5. Empirical Model of Real Imports of Services

\begin{tabular}{|c|c|c|c|c|c|c|c|c|c|c|c|c|c|c|c|c|c|c|c|}
\hline \multirow{4}{*}{$\begin{array}{l}\text { Sample } \\
\text { Estimation } \\
\text { Measure of Im port D emand: }\end{array}$} & \multicolumn{7}{|c|}{ Full Sample } & \multicolumn{6}{|c|}{ Advanced Economies } & \multicolumn{6}{|c|}{ Emerging Market and Developing Economies } \\
\hline & Panel & \multicolumn{6}{|c|}{ Country-S pecific } & Panel & \multicolumn{5}{|c|}{ Country-Specific } & Panel & \multicolumn{5}{|c|}{ Country-Specific } \\
\hline & IAD & \multicolumn{2}{|c|}{ IAD } & \multicolumn{2}{|c|}{ DIAD } & \multicolumn{2}{|c|}{$D I A D+X$} & IAD & \multirow{2}{*}{\multicolumn{2}{|c|}{$\begin{array}{l}\text { IAD } \\
\text { (6) }\end{array}$}} & \multirow{2}{*}{\multicolumn{2}{|c|}{$\begin{array}{c}\text { D IAD } \\
(7)\end{array}$}} & \multirow{2}{*}{$\frac{D I A D+X}{(8)}$} & IAD & \multirow{2}{*}{\multicolumn{2}{|c|}{$\begin{array}{l}A D \\
(10)\end{array}$}} & \multirow{2}{*}{\multicolumn{2}{|c|}{$\frac{D I A D}{(11)}$}} & \multirow{2}{*}{$\frac{\mathrm{D} I A D+X}{(12)}$} \\
\hline & (1) & & & & & & & (5) & & & & & & (9) & & & & & \\
\hline \multirow[t]{2}{*}{ Import Dem and } & 1.42 & \multicolumn{2}{|c|}{1.13} & \multicolumn{2}{|c|}{0.95} & \multicolumn{2}{|c|}{0.93} & 1.14 & \multicolumn{2}{|c|}{1.10} & \multicolumn{2}{|c|}{1.07} & 0.87 & 1.44 & \multicolumn{2}{|c|}{1.14} & \multicolumn{2}{|c|}{0.89} & 0.93 \\
\hline & $(0.33)$ & 0.72 & 1.81 & 0.49 & 1.43 & \multicolumn{2}{|c|}{0.30} & $(0.14)$ & 0.93 & 1.33 & 0.71 & 1.39 & 0.54 & $(0.35)$ & 0.70 & 1.97 & 0.36 & 1.44 & 0.22 \\
\hline & 0.04 & & & & & $\begin{array}{r}-0.04 \\
-0\end{array}$ & & -0.32 & & 08 & & & $\begin{array}{c}0.26 \quad 0.91 \\
-0.07\end{array}$ & 0.05 & -0.8 & & & & $\begin{array}{cc}-0.18 & 0.91 \\
-0.23\end{array}$ \\
\hline Relative Prices & $(0.21)$ & -0.63 & 0.06 & -0.61 & 0.10 & -0.61 & 0.10 & $(0.11)$ & -0.41 & 0.06 & -0.33 & 0.32 & $-0.51 \quad 0.17$ & $(0.21)$ & -0.71 & 0.05 & -0.66 & 0.00 & $\begin{array}{ll}-0.68 & 0.08\end{array}$ \\
\hline Constant & 0.01 & & 0 & & 1 & & & 0.01 & & 01 & & & 0.01 & 0.01 & 0.0 & & & & 0.00 \\
\hline & $(0.01)$ & -0.02 & 0.03 & -0.01 & 0.04 & -0.04 & 0.03 & $(0.00)$ & 0.00 & 0.02 & 0.01 & 0.04 & $-0.02 \quad 0.02$ & $(0.01)$ & -0.03 & 0.04 & -0.02 & 0.04 & $-0.05 \quad 0.04$ \\
\hline
\end{tabular}

Source: IMF staff calculations.

0.40

0.24
966

0.47

0.39

0.46

0.08
2628

0.38

0.26

0.38

Note: $I A D=$ import-intensity-adjusted demand; $D I A D=$ import-intensity-adjusted demand using only the domestic components of aggregate demand; DIAD+X = DIAD and exports predicted by trading partners' $D I A D$. The table presents results from estimating

equations (1), (4), and (6). Columns (1), (5), and (9) report point estimates and heteroscedasticity-robust standard errors in parentheses from estimating equation (1) in a panel framework including country fixed effects. The remaining columns report the average point estimates as well as the interquartile range of these estimates from a country-by-country estimation. Absorption is measured as import-intensity-adjusted aggregate demand based on all four components of G DP in columns (1), (2), (5), (6), (9), and (10). In the rest of the columns, absorption is proxied by the import-intensity-adjusted domestic demand. The specifications presented in columns (4), (8), and (12) also control for predicted exports, as estimated according to equation (6). 
Table 6. Residuals: Real Goods Import Growth

\begin{tabular}{|c|c|c|c|c|c|c|c|c|c|}
\hline & \multicolumn{3}{|c|}{ Full S a mple } & \multicolumn{3}{|c|}{ Advanced Economies } & \multicolumn{3}{|c|}{$\begin{array}{l}\text { Emerging Market and } \\
\text { Developing Economies }\end{array}$} \\
\hline & IAD & DIAD & $\mathrm{DIAD}+\mathrm{X}$ & IAD & DIAD & $\mathrm{DIAD}+\mathrm{X}$ & $\mathrm{IAD}$ & DIAD & $\mathrm{DIAD}+\mathrm{X}$ \\
\hline & (1) & $(2)$ & (3) & (4) & (5) & (6) & (7) & $(8)$ & (9) \\
\hline Indica tor 1985-2011 & $\begin{array}{c}0.003 \\
(0.002)\end{array}$ & $\begin{array}{l}0.001 \\
(0.003)\end{array}$ & $\begin{array}{l}0.001 \\
(0.002)\end{array}$ & $\begin{array}{c}0.003 \\
(0.002)\end{array}$ & $\begin{array}{c}0.001 \\
(0.003)\end{array}$ & $\begin{array}{c}0.001 \\
(0.002)\end{array}$ & $\begin{array}{l}0.003 \\
(0.005)\end{array}$ & $\begin{array}{l}0.000 \\
(0.007)\end{array}$ & $\begin{array}{l}0.002 \\
(0.006)\end{array}$ \\
\hline Indicator 2012-16 & $\begin{array}{l}-0.009 \\
(0.003)\end{array}$ & $\begin{array}{l}-0.023 \\
(0.004)\end{array}$ & $\begin{array}{l}-0.016 \\
(0.003)\end{array}$ & $\begin{array}{l}-0.005 \\
(0.002)\end{array}$ & $\begin{array}{l}-0.014 \\
(0.003)\end{array}$ & $\begin{array}{l}-0.009 \\
(0.003)\end{array}$ & $\begin{array}{l}-0.017 \\
(0.006)\end{array}$ & $\begin{array}{l}-0.040 \\
(0.007)\end{array}$ & $\begin{array}{l}-0.028 \\
(0.007)\end{array}$ \\
\hline Number of Obs ervations & 3531 & 3531 & 3531 & 942 & 942 & 942 & 2589 & 2589 & 2589 \\
\hline
\end{tabular}

Sources: IMF staff calculations

Notes : IAD = import-intens ity-adjus ted demand; DIAD = import-intens ity-adjus ted demand us ing only the domes tic components of aggregate demand; $D I A D+X=D I A D$ and exports predicted by trading partners' DIAD. The table reports point estimates and heteros cedas ticity-robust standard errors in parentheses from es timating equation (7). Regress ions are weighted by countries' nominal goods import shares.

Table 7. Residuals: Real Services Import Growth

\begin{tabular}{|c|c|c|c|c|c|c|c|c|c|}
\hline & \multicolumn{3}{|c|}{ Full S a mple } & \multicolumn{3}{|c|}{ Advanced Economies } & \multicolumn{3}{|c|}{$\begin{array}{l}\text { Emerging Market and } \\
\text { Developing Economies }\end{array}$} \\
\hline & $\mathrm{IAD}$ & DIAD & $\mathrm{DIAD}+\mathrm{X}$ & IAD & DIAD & $\mathrm{DIAD}+\mathrm{X}$ & IAD & DIAD & $\mathrm{DIAD}+\mathrm{X}$ \\
\hline & $(1)$ & $(2)$ & (3) & $(4)$ & $(5)$ & (6) & $(7)$ & $(8)$ & $(9)$ \\
\hline Indica tor 1985-2011 & $\begin{array}{c}0.002 \\
(0.003)\end{array}$ & $\begin{array}{c}0.001 \\
(0.003)\end{array}$ & $\begin{array}{c}0.002 \\
(0.003)\end{array}$ & $\begin{array}{l}-0.001 \\
(0.002)\end{array}$ & $\begin{array}{l}-0.002 \\
(0.002)\end{array}$ & $\begin{array}{l}-0.001 \\
(0.002)\end{array}$ & $\begin{array}{l}0.010 \\
(0.012)\end{array}$ & $\begin{array}{c}0.014 \\
(0.012)\end{array}$ & $\begin{array}{l}0.010 \\
(0.011)\end{array}$ \\
\hline Indica tor 2012-16 & $\begin{array}{c}0.009 \\
(0.006)\end{array}$ & $\begin{array}{l}-0.001 \\
(0.006)\end{array}$ & $\begin{array}{l}0.000 \\
(0.006)\end{array}$ & $\begin{array}{l}0.008 \\
(0.004)\end{array}$ & $\begin{array}{c}0.005 \\
(0.004)\end{array}$ & $\begin{array}{c}0.004 \\
(0.004)\end{array}$ & $\begin{array}{c}0.012 \\
(0.017)\end{array}$ & $\begin{array}{l}-0.014 \\
(0.018)\end{array}$ & $\begin{array}{l}-0.011 \\
(0.018)\end{array}$ \\
\hline Number of Obs ervations & 3465 & 3465 & 3465 & 941 & 941 & 941 & 2524 & 2524 & 2524 \\
\hline
\end{tabular}

Sources: $\mathbb{M F}$ s taff calculations

Notes: $\mathrm{IAD}=$ import-intens ity-adjus ted demand; $\mathrm{DIAD}=$ import-intens ity-adjus ted demand us ing only the domes tic components of aggregate demand; $D I A D+X=D I A D$ and exports predicted by trading partners' $D I A D$. The table reports point estimates and

heteros cedas ticity-robust standard errors in parenthes es from es timating equation (7). Regres sions are weighted by countries' nominal goods import shares. 
Table 8. Decomposing the Decline in Real Goods Import Growth: Full Sample

\begin{tabular}{|c|c|c|c|c|c|c|c|c|c|c|c|c|c|c|c|}
\hline & \multirow[b]{2}{*}{ Actual } & \multicolumn{7}{|c|}{ Import growth pre dicted by IAD model and its components } & \multicolumn{7}{|c|}{ Import growth pre dicted by DIAD $+\mathrm{X}$ modeland its components } \\
\hline & & Overall & $\mathrm{C}$ & G & I & $\mathrm{X}$ & $\begin{array}{c}\text { Re la tive } \\
\text { Prices }\end{array}$ & Const & Overall & $\mathrm{C}$ & G & I & $\mathrm{X}$ & $\begin{array}{c}\text { Re la tive } \\
\text { Prices }\end{array}$ & Const \\
\hline & $(1)$ & $(2)$ & $(3)$ & $(4)$ & $(5)$ & $(6)$ & $(7)$ & $(8)$ & $(9)$ & $(10)$ & $(11)$ & $(12)$ & $(13)$ & $(14)$ & $(15)$ \\
\hline $1985-2007$ & 8.1 & 8.0 & 1.4 & 0.7 & 2.7 & 4.6 & 0.3 & -1.9 & 7.8 & 1.5 & 0.8 & 2.9 & 4.6 & 0.3 & -2.3 \\
\hline $2003-2007$ & 9.0 & 8.9 & 1.4 & 0.7 & 3.5 & 4.8 & 0.2 & -1.7 & 9.2 & 1.5 & 0.7 & 3.6 & 5.2 & 0.3 & -2.1 \\
\hline $2012-2016$ & 2.2 & 3.1 & 0.9 & 0.4 & 1.4 & 1.8 & 0.2 & -1.7 & 3.6 & 1.0 & 0.4 & 1.6 & 2.7 & 0.1 & -2.1 \\
\hline \multicolumn{16}{|c|}{ Average Growth in 2012-16 minus average growth in: } \\
\hline $1985-2007$ & -5.9 & -4.9 & -0.5 & -0.3 & -1.3 & -2.8 & -0.1 & 0.2 & -4.1 & -0.5 & -0.3 & -1.3 & -1.8 & -0.3 & 0.2 \\
\hline $2003-2007$ & -6.8 & -5.8 & -0.5 & -0.2 & -2.0 & -3.0 & 0.0 & 0.0 & -5.6 & -0.5 & -0.3 & -2.1 & -2.5 & -0.3 & 0.0 \\
\hline \multicolumn{16}{|c|}{ Fraction of the Import Growth Decline Predicted by Model } \\
\hline $1985-2007$ & & 0.84 & & & & & & & 0.71 & & & & & & \\
\hline $2003-2007$ & & 0.86 & & & & & & & 0.83 & & & & & & \\
\hline
\end{tabular}

Source: IMF s taffcalcula tions.

Notes: $I A D=$ import-intens ity-a djus te d demand; DIAD = import-intensity-a djus te d demand us ing only the domestic components of a ggre ga te de mand; DIAD $+X=$ DIAD and exports predicted by trading partners' DIAD. The table reports actual and predicted real goods import growth rates. Individual economies' growth rates are aggregated using average import shares over the 1985-2016 period to minimize fluctuations in the contribution of the constant to aggregate import growth. Columns (2)-(8) decompose predicted import growth based on equation (1). Columns (9)-(15) decompose predicted import growth based on equation (6), with column (13) denoting the contribution of export growth predicted based on trading partners' import-intensity-adjusted domestic demand. 
Table 9. Decomposing the Decline in Real Goods Import Growth: Advanced Economies

\begin{tabular}{|c|c|c|c|c|c|c|c|c|c|c|c|c|c|c|c|}
\hline & \multirow[b]{2}{*}{ Actual } & \multicolumn{7}{|c|}{ Import growth pre dicted by IAD modeland its components } & \multicolumn{7}{|c|}{ Import growth pre dicted by DIAD $+X$ mode land its components } \\
\hline & & Overall & $\mathrm{C}$ & G & I & $\mathrm{X}$ & $\begin{array}{c}\text { Relative } \\
\text { Prices }\end{array}$ & Const & Overall & $\mathrm{C}$ & $\mathrm{G}$ & I & $\mathrm{X}$ & $\begin{array}{c}\text { Re lative } \\
\text { Prices }\end{array}$ & Const \\
\hline & $(1)$ & $(2)$ & (3) & $(4)$ & $(5)$ & $(6)$ & $(7)$ & $(8)$ & $(9)$ & $(10)$ & $(11)$ & $(12)$ & $(13)$ & $(14)$ & $(15)$ \\
\hline $1985-2007$ & 6.8 & 6.9 & 1.1 & 0.5 & 2.0 & 4.0 & 0.1 & -0.8 & 6.7 & 1.2 & 0.5 & 2.0 & 4.0 & 0.1 & -1.0 \\
\hline $2003-2007$ & 6.9 & 6.8 & 0.9 & 0.4 & 2.0 & 4.1 & 0.1 & -0.7 & 7.4 & 1.0 & 0.3 & 1.8 & 4.9 & 0.2 & -0.9 \\
\hline $2012-2016$ & 2.3 & 2.8 & 0.6 & 0.2 & 1.0 & 1.8 & 0.0 & -0.7 & 3.2 & 0.6 & 0.1 & 1.1 & 2.4 & -0.2 & -0.9 \\
\hline \multicolumn{16}{|c|}{ Average Growth in $2012-16$ minus average growth in: } \\
\hline $1990-2007$ & -4.4 & -4.1 & -0.6 & -0.3 & -1.0 & -2.2 & -0.1 & 0.1 & -3.5 & -0.5 & -0.3 & -0.9 & -1.6 & -0.2 & 0.1 \\
\hline $2003-2007$ & -4.6 & -4.0 & -0.3 & -0.2 & -1.0 & -2.4 & -0.1 & 0.0 & -4.2 & -0.3 & -0.2 & -0.7 & -2.5 & -0.4 & 0.0 \\
\hline \multicolumn{16}{|c|}{ Fraction of the Import Growth Decline Predicted by Model } \\
\hline $1985-2007$ & & 0.91 & & & & & & & 0.79 & & & & & & \\
\hline $2003-2007$ & & 0.88 & & & & & & & 0.92 & & & & & & \\
\hline
\end{tabular}

Source: MF staffcalculations.

Note $\mathrm{s}: \mathrm{IAD}=$ import-intens ity-a djus ted de mand; DIAD = import-intens ity-a djus te d de mand us ing only the dome stic components of a ggre gate de mand; DIAD $+\mathrm{X}=$ DIAD and exports predicted by trading partners' DIAD. The table reports actual and predicted real goods import growth rates. Individual economies' growth rates are aggregated using average import shares over the 1985-2016 period to minimize fluctuations in the contribution of the constant to aggregate import growth. Columns (2)-(8) decompose predicted import growth based on equation (1). Columns (9)-(15) decompose predicted import growth based on equation (6), with column (13) denoting the contribution of export growth predicted based on trading partners' import-intensity-adjusted domestic demand. 
Table 10. Decomposing the Decline in Real Goods Import Growth: Emerging Market and Developing Economies

\begin{tabular}{|c|c|c|c|c|c|c|c|c|c|c|c|c|c|c|c|}
\hline & \multirow[b]{2}{*}{ Actual } & \multicolumn{7}{|c|}{ Import growth pre dicted by IAD model and its components } & \multicolumn{7}{|c|}{ Import growth pre dicted by DIAD $+\mathrm{X}$ mode 1 and its components } \\
\hline & & Overall & $\mathrm{C}$ & G & I & $\mathrm{X}$ & $\begin{array}{l}\text { Relative } \\
\text { Prices }\end{array}$ & Const & Overall & $\mathrm{C}$ & G & I & $\mathrm{X}$ & $\begin{array}{l}\text { Relative } \\
\text { Prices }\end{array}$ & Const \\
\hline & $(1)$ & $(2)$ & (3) & (4) & $(5)$ & $(6)$ & $(7)$ & $(8)$ & $(9)$ & $(10)$ & $(11)$ & $(12)$ & $(13)$ & $(14)$ & $(15)$ \\
\hline $1985-2007$ & 11.1 & 10.4 & 2.2 & 1.3 & 4.5 & 6.3 & 0.8 & -4.6 & 10.3 & 2.4 & 1.5 & 5.1 & 6.0 & 0.9 & -5.7 \\
\hline 2003-2007 & 13.7 & 13.6 & 2.7 & 1.4 & 6.9 & 6.5 & 0.3 & -4.1 & 13.5 & 2.9 & 1.5 & 7.8 & 5.8 & 0.6 & -5.1 \\
\hline $2012-2016$ & 1.9 & 3.7 & 1.6 & 1.0 & 2.4 & 2.1 & 0.7 & -4.1 & 4.8 & 1.8 & 1.1 & 2.7 & 3.6 & 0.7 & -5.1 \\
\hline \multicolumn{16}{|c|}{ Average Growth in 2012-16 minus average growth in: } \\
\hline $1985-2007$ & -9.2 & -6.8 & -0.5 & -0.3 & -2.1 & -4.2 & -0.1 & 0.5 & -5.5 & -0.6 & -0.4 & -2.4 & -2.5 & -0.3 & 0.6 \\
\hline $2003-2007$ & -11.8 & -9.9 & -1.0 & -0.4 & -4.5 & -4.4 & 0.4 & 0.0 & -8.8 & -1.0 & -0.4 & -5.1 & -2.3 & 0.1 & 0.0 \\
\hline \multicolumn{16}{|c|}{ Fraction of the Import Growth Decline Predicted by Model } \\
\hline $1985-2007$ & & 0.74 & & & & & & & 0.60 & & & & & & \\
\hline $2003-2007$ & & 0.84 & & & & & & & 0.74 & & & & & & \\
\hline
\end{tabular}

Source: MF staffcalculations

Note $\mathrm{s}$ : $\mathrm{AD}=$ import-intens ity-a djus te d de mand; DIAD = import-intens ity-a djuste d de mand us ing only the domes tic components of aggre gate de mand; DIAD $+\mathrm{X}=$ DIAD and exports predicted by trading partners' DIAD. The table reports actual and predicted real goods import growth rates. Individual economies' growth rates are aggregated using average import shares over the 1985-2016 period to minimize fluctuations in the contribution of the constant to aggregate import growth. Columns (2)-(8) decompose predicted import growth based on equation (1). Columns (9)-(15) decompose predicted import growth based on equation (6), with column (13) denoting the contribution of export growth predicted based on trading partners' import-intensity-adjusted domestic demand. 


\section{REFERENCES}

Alessandria, George and Horag Choi. 2016. "The Dynamics of the U.S. Trade Balance and Real Exchange Rate: The J Curve and Trade Costs?" mimeo.

Alessandria, George, Joseph Kaboski, and Virgiliu Midrigan. 2013. "Trade Wedges, Inventories and International Business Cycles." Journal of Monetary Economics 60: $1-20$

Amiti, Mary, Tyler Bodine-Smith, Colin Hottman, and Logan Lewis (2016) "What's driving the recent slump in US imports?" Federal Reserve Board, IFDP note.

Aslam, Aqib, Emine Boz, Eugenio Cerutti, Marcos Poplawski-Ribeiro and Petia Topalova (forthcoming) "Explaining the Global Trade Slowdown: The Role of Trade Costs and Global Value Chain Participation.” IMF Working Paper, forthcoming.

Boz, Emine, Matthieu Bussière, Clément Marsilli, 2015. "Recent slowdown in global trade: Cyclical or Structural?" In Bernard Hoekman. 2015. The Global Trade Slowdown: A New Normal? Vox EU E-book, Chapter 3 (London: Centre for Economic Policy Research) http://www.voxeu.org/article/recent-slowdown-global-trade

Bussière, Matthieu, Giovanni Callegari, Fabio Ghironi, Giulia Sestieri, and Norihiko Yamano. 2013. "Estimating Trade Elasticities: Demand Composition and the Trade Collapse of 2008-09." American Economic Journal: Macroeconomics 5 (3): 118-51.

Chari, Varadarajan V., Patrick J. Kehoe, Ellen McGrattan, 2007. "Business Cycle Accounting." Econometrica 75 (3): 781:836.

Constantinescu, Cristina, Aaditya Mattoo, and Michele Ruta, 2015. "The Global Trade Slowdown: Cyclical or Structural?” IMF Working Paper No. 15/6 (Washington: International Monetary Fund).

Dekle, Robert, Jonathan Eaton and Samuel Kortum, 2007. "Unbalanced Trade." American Economic Review: Papers and Proceedings 67 (4): 351-5.

Eaton, Jonathan and Samuel Kortum, 2002. "Technology, Geography, and Trade." Econometrica 70 (5): 1741-79.

Eaton, Jonathan, Samuel Kortum, Brent Neiman, John Romalis, 2010. "Trade and the Global Recession.” National Bank of Belgium Working Paper Research No. 196, October, Brussels.

Eaton, Jonathan, Samuel Kortum, Brent Neiman, John Romalis, 2016. "Trade and the Global Recession." American Economic Review, 106(11): 3401-38. 
European Central Bank, IRC Trade Task Force (2016) "Understanding the weakness in global trade: What is the new normal?", ECB Occasional Paper, No 178.

Freund, Caroline, 2016. “The Global Trade Slowdown and Secular Stagnation,” Peterson Institute of International Economics blog, https://piie.com/blogs/trade-investmentpolicy-watch/global-trade-slowdown-and-secular-stagnation

Hoekman, Bernard, ed. 2015. The Global Trade Slowdown: A New Normal? Available at http://voxeu.org/sites/default/files/file/Global\%20Trade\%20Slowdown_nocover.pdf.

Hong, Gee Hee, Jaewoo Lee, Wei Liao and Dulani Seneviratne. 2016. "China and Asia in the Global Trade Slowdown.” IMF Working Paper 16/105 (Washington: International Monetary Fund).

International Monetary Fund (IMF). 2015a. April 2015 World Economic Outlook (Box 1.2. "Understanding the Role of Cyclical and Structural Factors in the Global Trade Slowdown.”) Washington.

International Monetary Fund (IMF). 2015b. April 2015 World Economic Outlook, "Private Investment: What is the Holdup?" Chapter 4, Washington.

. 2016a. April 2016 World Economic Outlook, "Understanding the Slowdown in Capital Flows to Emerging Markets," Chapter 2, Washington.

. 2016b. October 2016 World Economic Outlook, Chapter 2, “Global Trade: What's Behind the Slowdown?" Chapter 2, Washington.

Jääskelä, Jarkko and Thomas Mathews. 2015. "Explaining the Slowdown in Global Trade." Reserve Bank of Australia Bulletin, September, 39-46.

Kindberg-Hanlon, Gene, and David Young. 2016. "The world trade slowdown (redux)", Bank of England Blog.

Levchenko, Andrei, Logan Lewis, and Linda Tesar. 2010. "The Collapse of International Trade during the 2008-09 Crisis: In Search of the Smoking Gun." IMF Economic Review, 58(2): 214-253.

Lewis, Logan, and Ryan Monarch (2016) "Causes of the global trade slowdown”, Federal Reserve Board, IFDP Note, Washington: Board of Governors of the Federal Reserve System, November.

Martinez-Martin, Jaime. 2016. "Breaking Down World Trade Elasticities: A Panel ECM Approach.” Bank of Spain Working Paper No. 1614.

Morel, Louis. 2015. "Sluggish Exports in Advanced Economies: How Much is Due to Demand" Bank of Canada Discussion Paper No. 2015-3. 
OECD (2016) "Cardiac arrest or dizzy spell: Why is world trade so weak and what can policy do about it?”, OECD, Economic Policy Paper, 18.

Ollivaud, Patrice, and Cyrille Schwellnus, 2015. "Does the Post-Crisis Weakness in Global Trade Solely Reflect Weak Demand?” OECD Economics Department Working Paper No. 1216.

Powell, Jerome H. 2016. "The global trade slowdown and its implications for emerging Asia”, speech delivered at CPBS 2016 Pacific Basin Research Conference.

Slopek, Ulf. 2015. "Why has the Income Elasticity of Global Trade Declined?" Deutsch Bundesbank, Economics Department, unpublished manuscript.

Timmer, Marcel P., Bart Los, Robert Stehrer and Gaaitzen J. de Vries. 2016. "An anatomy of the global trade slowdown based on the WIOD 2016 release", GGDC research memorandum number 162, University of Groningen. 